\title{
76. SUBSIDENCE OF THE JAPAN SEA: STRATIGRAPHIC EVIDENCE FROM ODP SITES AND ONSHORE SECTIONS ${ }^{1}$
}

\author{
James C. Ingle, Jr. ${ }^{2}$
}

\begin{abstract}
Abundant geologic, geophysical, and paleontologic evidence from ODP drilling in the Japan Sea and from adjacent continental and insular areas demonstrates that the sea has evolved rapidly over the past $32 \mathrm{~m} . \mathrm{y}$. and is now in an early stage of compressive destruction. Stratigraphic, geochronologic, and paleobathymetric data derived from ODP Sites 794, 795, 796, 797, 798, and 799. offshore exploration wells, and uplifted and deformed Neogene stratigraphic sections exposed on the Korean Peninsula and the islands of Honshu, Hokkaido, and Sakhalin were used to analyze the timing and patterns of backarc subsidence characterizing each stage in the evolution of the Japan Sea. An extensional tectonic regime and subsidence dominate backarc evolution ca. 32 Ma to $10 \mathrm{Ma}$ at which time regional uplift was initiated marking the onset of a compressional regime that continues to the present. Backstripping techniques were applied to five Neogene stratigraphic columns in contrasting depositional, crustal, and tectonic settings to derive estimates of variations in rates of total and tectonically driven subsidence, presumably reflecting fundamental changes in crustal behavior during backarc evolution. The five Neogene sequences analyzed include; (1) the Pohang onshore section on the southeastern Korean Peninsula, (2) the Dolgorae-1 offshore well in the southern Tsushima Basin, (3) the Oga Peninsula onshore section in northwestern Honshu, (4) ODP Site 794 at the juncture between the Japan and Yamato basins, and (5) the southern Sakhalin onshore section representing the northern margin of the Japan Sea.

Initial rifting, extension, and thermal subsidence in the Japan Sea region commenced in late Oligocene time (ca. 32-25 Ma) at rates of $<150 \mathrm{~m} / \mathrm{m} . \mathrm{y}$. accompanied by widespread deposition of non-marine sediment and volcanic units and probable early spreading in the Japan Basin. A period of accelerating subsidence (100-500 m/m.y.), backarc spreading, rift propagation, massive basaltic magmatism, and crustal extension began in the early Miocene ca. 24-23 Ma culminating in subsidence of the Japan, Yamato, and Tsushima basins to near their present depths ( $2-3 \mathrm{~km})$ by $20-18 \mathrm{Ma}$. Slow subsidence persisted from $18 \mathrm{Ma}$ to $16-15$ Ma when a second episode of rapid subsidence occurred as rifts propagated into the arc, arc-flanks, and other areas of weakened continental crust around the perimeter of the sea creating numerous sub-basins accompanied by middle Miocene rotation of southwest Japan and a second pulse of basaltic magmatism. Maximum rates of tectonic subsidence during middle Miocene sub-basin formation exceeded $900 \mathrm{~m} / \mathrm{m}$.y. pointing to a pull-apart origin for these features which were initially sediment-starved and filled with pelagic and hemipelagic diatomaceous muds. Relatively low rates of subsidence $(<200 \mathrm{~m} / \mathrm{m}$.y. $)$ characterize the tectonically quiescent middle-late Miocene stage in the evolution of the sea from 12.5 to $10 \mathrm{Ma}$. Evidence of initial regional uplift (10-100 m/m.y.) appears in the southern Japan Sea ca. 11-10 Ma with compressional uplift and destruction of Miocene sub-basins in arc and arc-flank areas of Honshu, Hokkaido, and Sakhalin ca. 5 Ma. Rates of uplift subsequently accelerated to 500-1500 $\mathrm{m} / \mathrm{m} . \mathrm{y}$. in late Pliocene and Pleistocene time (2.0-0.7 Ma) resulting in widespread deformation of pre-upper Pleistocene sedimentary sequences and the tectonic reorganization of the eastern, central, and southern Japan Sea creating the borderland-style topography now characterizing these areas.
\end{abstract}

\section{INTRODUCTION}

With the successful completion of ODP Legs 127 and 128, the Japan Sea now stands as the best studied of the many backarc basins that characterize the western margin of the Pacific Ocean. This is the case largely because of the abundance of geological and geophysical data available from the islands and continental margins surrounding the sea as well as from offshore marine studies in the sea proper (Fig. 1). Although in 1973 DSDP Leg 31 sampled the younger part of the Neogene sediment blanket in the Japan Sea (Karig, Ingle, et al., 1975), drilling failed to reach the base of the Neogene column leaving questions of crustal age and subsidence unanswered. In effect, ODP penetration of the Yamato and Japan basins in 1989 provided the missing evidence needed to reconstruct the first comprehensive picture of the evolution of the Japan Sea (Figs. 1 and 2). ODP drilling not only allowed sampling and dating of the volcanic rocks flooring the deep basins of the Japan Sea but also provided multiple evidence that these same basins had subsided to bathyal depths by early Miocene time. Taken together, onshore, offshore, and newly acquired ODP data collectively demonstrate that the Japan Sea formed in a

' Tamaki, K., Suyehiro, K., Allan, J., McWilliams, M., et al., 1992, Proc. ODP, Sci. Results, 127/128, Pt. 2: College Station, TX (Ocean Drilling Program).

${ }^{2}$ Department of Geology, Stanford University, Stanford, CA $94305-2115$, U.S.A. continental arc setting in mid-Tertiary time, underwent extension, backarc spreading, and subsidence in early and middle Miocene time, and is now undergoing compressive deformation and the early stages of tectonic destruction.

The purposes of this report are to (1) summarize evidence of the timing, rates, and magnitude of subsidence marking the evolution of the Japan Sea using data from selected onshore, offshore, and ODP stratigraphic sequences and (2) identify the patterns of subsidence characterizing each stage in the development of the sea. The basic assumption inherent in this study is that patterns of subsidence and uplift recorded by individual stratigraphic columns directly reflect the character and interaction of the fundamental depositional and crustal processes determining basin evolution. The implications and integration of subsidence histories derived from this study together with other evidence bearing on the overall tectonic evolution of the Japan Sea are discussed in the synthesis by Tamaki et al. (this volume).

The principle techniques employed to analyze basin subsidence and uplift were backstripping and so-called geohistory analysis. Both of these techniques make use of stratigraphic data to (1) quantitatively reconstruct the history of sediment accumulation, burial, compaction, and subsidence recorded by a given sedimentary column and (2) isolate the tectonic components of vertical motion from subsidence attributable to isostatic compensation of the underlying basement/crust caused by sediment and water loading. 


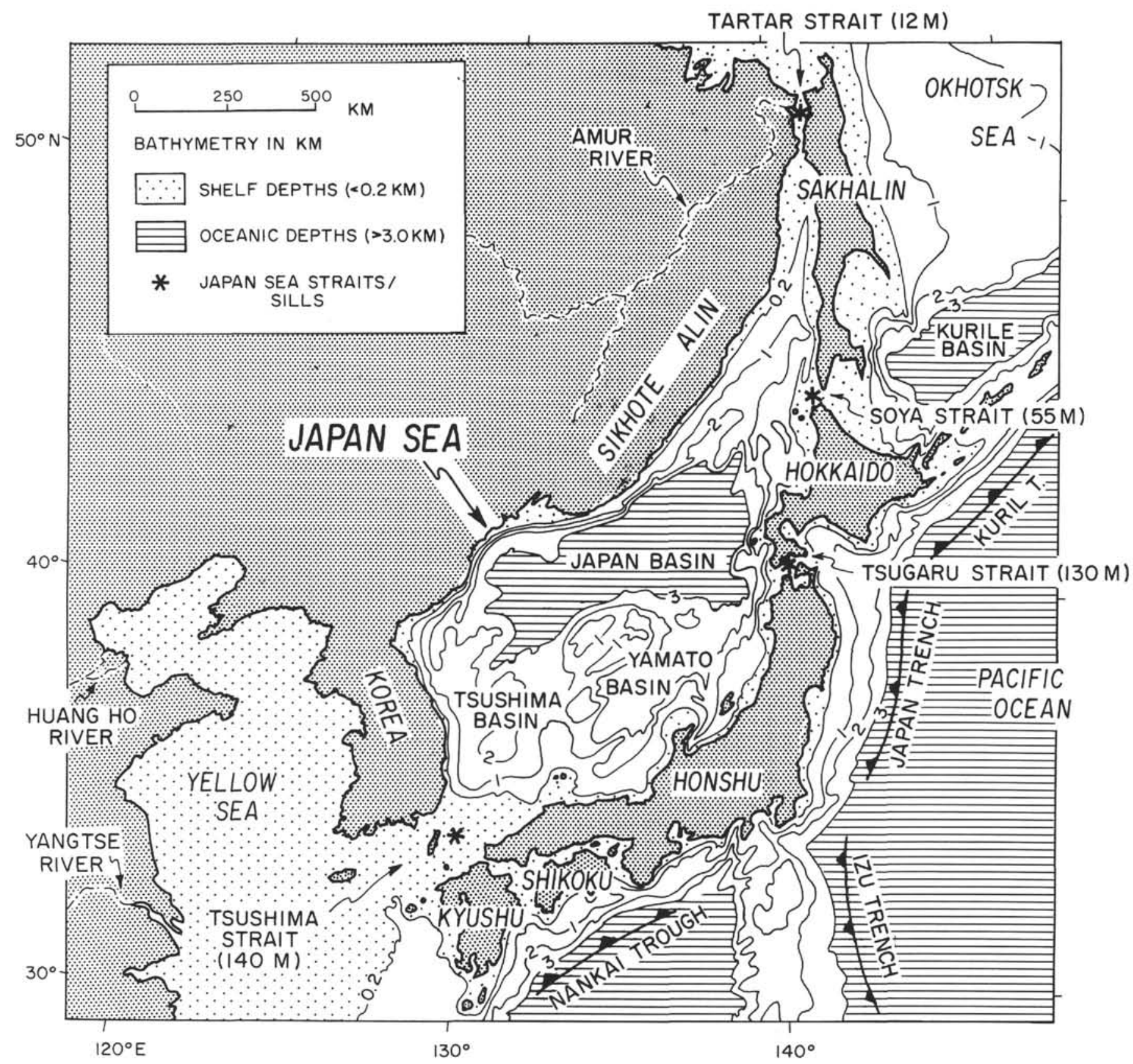

Figure 1. Location of ODP drilling sites in the Japan Sea and locations of important Neogene sequences exposed onshore or known from subsurface exploration. Also shown is the location of DSDP Sites 438 and 439 where drilling penetrated the Neogene Ishikari-Hidaka forearc basin.

Fortunately, uplifted and deformed Neogene sedimentary sequences are widely exposed around the southern and eastern margins of the Japan Sea (Fig. 1), and many have been studied in detail in the course of basic scientific inquiry and the exploration for petroleum and other mineral resources. Previous paleobathymetric and paleoenvironmental studies of surface and subsurface sequences in northern Honshu demonstrate that the majority of the sub-basins formed along the eastern margin of the evolving Japan Sea experienced rapid subsidence to bathyal water depths in early middle Miocene time ca. 16-15 Ma (Asano et al., 1969; Ingle, 1975, 1981; Kitazato, 1979; Sugi et al., 1983; Guber and Merrill, 1983; Matoba, 1983; Iijima et al., 1988; Hoshi, 1988; Yamaji and Sato, 1989; Iijima and Tada, 1990; Fig. 3). However, quantitative analysis of the thick Neogene column penetrated by the Dolgorae-1 Well on the southern margin of the Tsushima Basin (Fig. 1) illustrates that rapid subsidence commenced in this area during early Miocene time (Chough and Barg, 1987), similar to the early Miocene subsidence history revealed through ODP drilling for the adjacent Yamato Basin (Tamaki, Pisciotto, Allen, et al., 1990; Ingle, Suyehiro, von Breymann, et al., 1990)).

Key onshore sequences chosen for subsidence analysis include the Pohang section in southeastern Korea, the Oga Peninsula section in northeastern Honshu, and the Makarov River section in southern Sakhalin (Fig. 1). Offshore sequences utilized in this study include the Dolgorae-1 Well in the southern Tsushima (Ulleung) Basin as analyzed by Chough and Barg (1987) and the six ODP sites drilled in the Japan Sea including Sites 794, 795, 796, 797, 798, and 799 (Fig. 1). All six ODP sites yielded important paleobathymetric data and evidence of subsidence and/or uplift within the major deep basins of the Japan Sea. However, the stratigraphic column at Site 794 was specifically selected for quantitative subsidence analysis because 


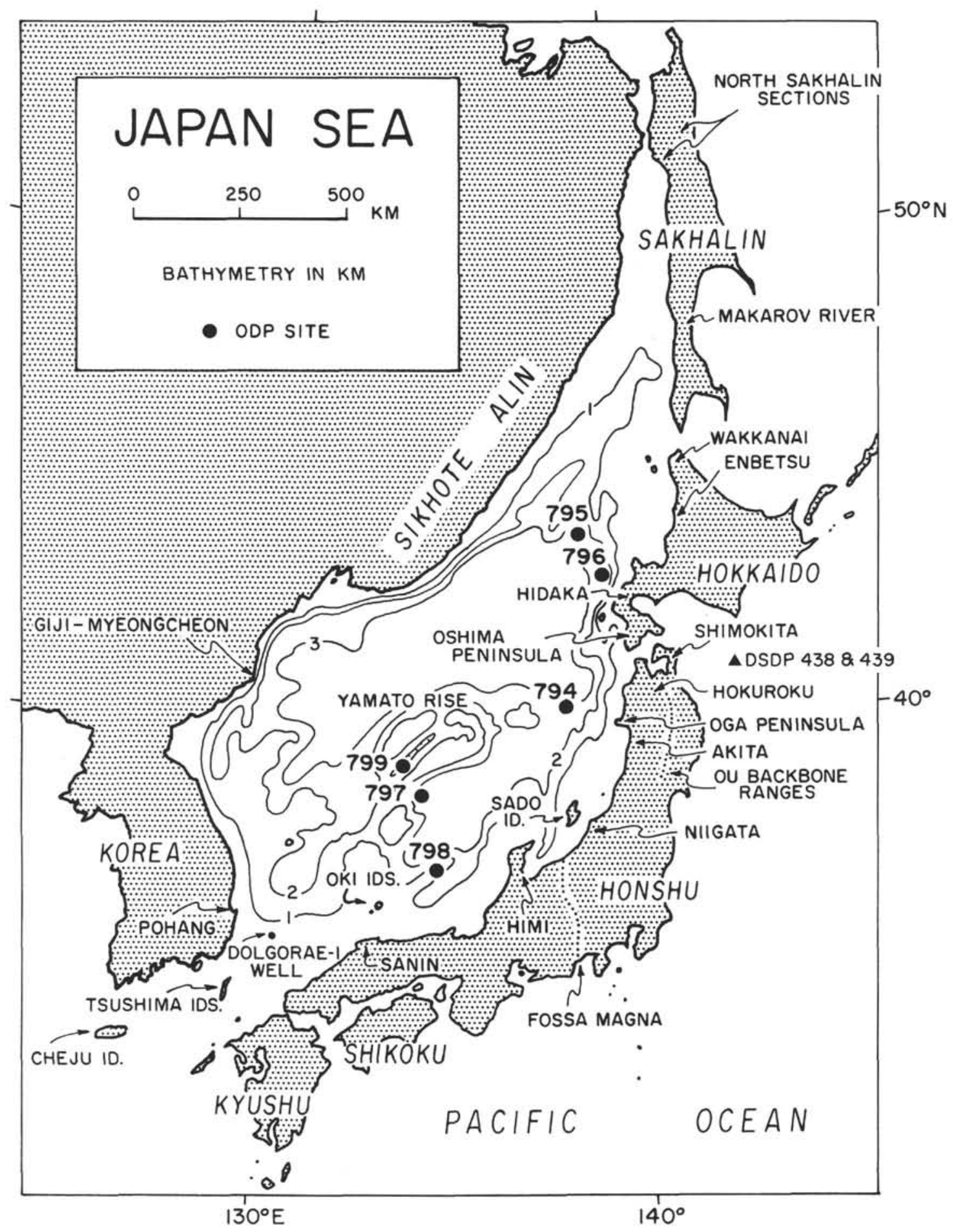

Figure 2. Generalized bathymetry in the Japan Sea region emphasizing areas of oceanic water depth $(>3 \mathrm{~km})$ and areas of shelf depth $(<0.2 \mathrm{~km})$. Note the presence of oceanic water depths in the Japan Basin and the extremely shallow straits separating the Japan Sea from the adjacent Pacific Ocean. Figure modified from Ingle, Suyehiro, von Breymann, et al. (1990).

of its critical location at the juncture between the Yamato and Japan basins (Figs. 1 and 2). Finally, evidence from DSDP Sites 438 and 439 presented by von Huene and Arthur (1982) provides insights into the Neogene subsidence of the Ishikari-Hidaka basin off northeastern Honshu (Fig. 1) allowing comparison of patterns of subsidence and uplift in both forearc and backarc areas of the Japan Sea during its evolution.

\section{METHODS}

\section{Subsidence Analysis}

As sediments accumulate in a subsiding basin, they simultaneously undergo compaction, loss of porosity and original thickness, and present a cumulative load inducing isostatic adjustment of the underlying crust 


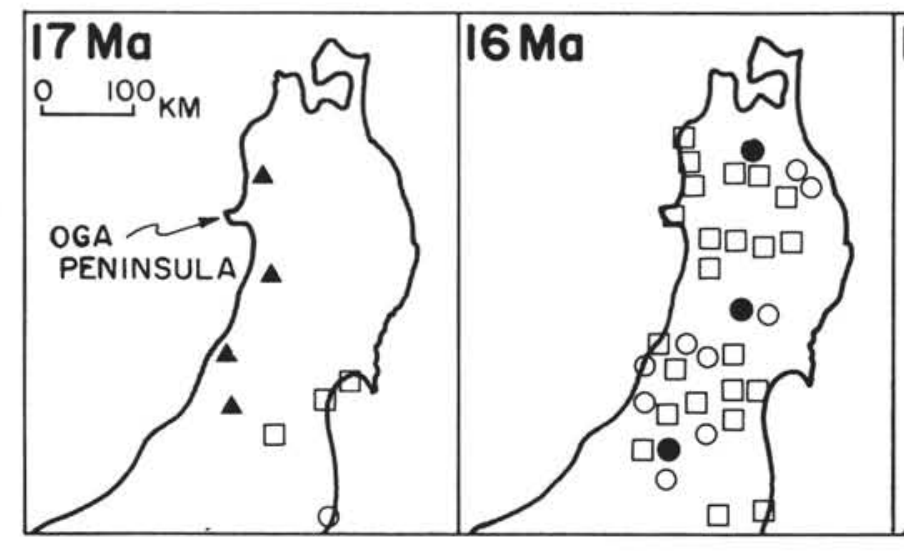

- NON-MARINE

NERITIC

O UPPER BATHYAL
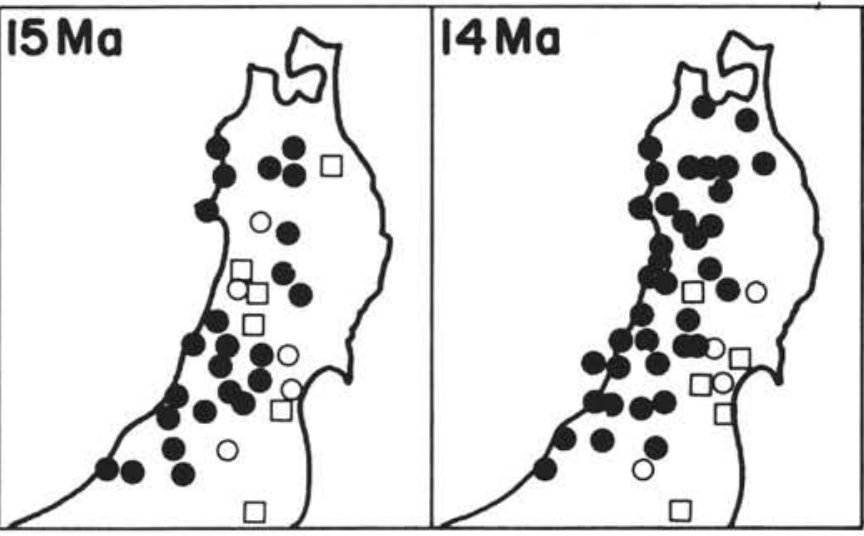

Figure 3. Summary of early and middle Miocene paleobathymetric changes expressed in selected surface and subsurface sections in northern Honshu, Japan, as analyzed by Yamaji and Sato (1989).

with successive depositional surfaces buried to ever increasing depths with time. Geohistory and backstripping analysis seek to reverse or invert this process in order to derive quantitative estimates of variations in subsidence and/or uplift expressed within local stratigraphic sequences. Variations in lithology and assumed original porosities allow a given sediment column to be sequentially decompacted and sedimentary thicknesses removed or "backstripped" through time so to remove the effects of isostatic loading. The application of these procedures yields plots or curves expressing variations in subsidence and uplift over time, reflecting thereby the vertical motion of the crust/substratum underlying any column analyzed.

This study followed the basic procedures for geohistory and backstripping analysis originally set forth by van Hinte (1978) and Steckler and Watts (1978) and more recently summarized by Miall (1983, p. 319), Mayer (1987, 1991), and Allen and Allen (1990, p. 263) wherein data on variations in age, thickness, lithology, and paleobathymetry for a given stratigraphic column are used to; (1) plot time-depth trajectories of individual stratigraphic horizons, (2) calculate decompacted (unloaded) sediment thicknesses, and (3) systematically remove (backstrip) local isostatic loading effects on the underlying crust/substratum created by accumulation of sediment and changing water depth over time.

Backstripping of stratigraphic sequences including decompaction of sediment and calculation of the isostatic component of subsidence was carried out using a computer program developed at the University of Arizona by Dickinson et al. (1987). Significantly, the empirical lithology-porosity-depth formulas utilized in this program have been amended to include a ratio for diagenically altered diatomaceous sediment (e.g., porcellanite) as derived by Roger Bloch of Stanford University (pers. comm., 1989). This latter ratio is of special advantage because altered diatomaceous mud and porcellanite represent common lithologies within the Neogene sequences of the Japan Sea (e.g., Iijima et al., 1988; Tamaki, Pisciotto, Allen, et al., 1990). As noted by Dickinson et al. (1987) and McCrory (1989), this subsidence model assumes that cumulative sediment and water loads imposed on a given crustal block are compensated locally through simple Airy isostatic mechanisms without regard for variations in lateral strength or areal flexure of the crust/lithosphere. An appropriate isostatic correction is thus applied during backstripping of the stratigraphic column to systematically remove the effects of loading on the elevation of the underlying substratum/crust. Any residual values of subsidence or uplift remaining after the effects of loading are removed are assumed to represent a quantitative measure of tectonically driven vertical motion induced by the mechanical and/or thermal systems modulating basin evolution (e.g., faulting, crustal thinning, thermal decay, variations in mantle character, lithospheric flexure, etc.). Hence, values of residual vertical motion define a so-called tectonic curve of subsidence/uplift.

Alternatively, the so-called total subsidence curve derived for a given column expresses the cumulative isostatic effects caused by variations in water depth (paleobathymetry) and decompacted sediment thickness over time together with tectonically induced subsidence and/or uplift. The computer program also utilizes a correction for variations in water depth imparted by changes in eustatic sea level with time following the eustatic curve of Haq et al. (1987). However, the estimated range of variation in eustatic sea level during Neogene time is so small relative to the total range in paleobathymetry encompassed during subsidence of the Japan Sea $(>3000 \mathrm{~m})$ that eustatic events have negligible effect on the resulting subsidence curves and are not illustrated at the scales used.

Among the four key stratigraphic variables utilized in geohistory and backstripping analysis, stratigraphic thickness is commonly the easiest to establish and is well constrained for all of the sequences analyzed in this study. Similarly, variations in lithology are also well known for all of the sections used, which allows the relative proportions of each basic lithotype (conglomerate, sandstone, etc.) to be estimated for each stratigraphic interval and used together with the empirical porosity-depth formulas of Dickinson et al. (1987) to calculate decompacted sediment thicknesses.

In contrast to relatively uniform thickness and lithofacies data, age control varies as a function of the quality and quantity of biostratigraphic, magnetostratigraphic, and radiometric data available in each section and resulting correlations with the radiometric time scale. Specific sources of age data are cited within individual discussions of each section analyzed. The time scale of Berggren et al. (1985) is used as the standard for radiometric ages assigned to Neogene epoch and subepoch boundaries with the exception of the middle/late Miocene boundary which is placed at 9.5 Ma following Barron et al. (1985) and Barron (1986).

Paleobathymetric curves were constructed for each of the sections analyzed using available data on benthic foraminifers and lithofacies as discussed below.

\section{Paleobathymetry}

Estimates of paleobathymetry are critical to accurate geohistory analysis, especially within the context of tectonically active margin basins (Hayward, 1990). Indeed, the large and rapid changes of water depth common to active margin basins literally control or drive the shape of subsidence curves calculated for columns deposited in these settings. Hence, errors in paleobathymetry have far larger conse- 
quences for subsidence analysis of tectonically active basins than errors in decompaction or backstripping calculations as emphasized by Dickinson et al. (1987).

Asano et al. (1969) early recognized the bathyal character of benthic foraminifers in Neogene sequences in northern Honshu and presented quantitative paleobathymetric histories for six sub-basins formed during Miocene rifting of the Japan Sea with maximum water depths estimated to be ca. $2000 \mathrm{~m}$. Subsequent quantitative interpretations of the paleobathymetric history of both surface and subsurface Neogene sequences in the Japan Sea region have also relied on variations in fossil benthic foraminiferal assemblages (see, e.g., reports by Ingle, 1975, 1981; Hasegawa, 1979; Kitazato, 1979; Guber and Merrill, 1983; Ikuji, 1986; Nomura, 1986; Sato and Kudo, 1986; and Fukasawa, 1990).

Estimates of water depth or paleobathymetry made during this study are based upon interpretations of bathymetrically significant benthic foraminifera reported from the stratigraphic sections analyzed using the Neogene paleobathymetric biofacies erected by Hasegawa et al. (1989) as based on analogy with Recent foraminiferal distributions along the Pacific margin of Japan and within the Japan Sea. Estimated maximum and minimum water depths are depicted by bars on paleobathymetric curves using ranges noted by Hasegawa et al. (1989) and the bathymetric scale of Akimoto and Hasegawa (1989).

Conservative water depths have been purposely assigned to benthic foraminiferal biofacies to derive minimum estimates of rates and patterns of subsidence rather than maximum possible values. For example, the maximum water depths assigned to the deepest dwelling benthic biofacies recorded within the filled marginal sub-basins of the Japan Sea are 2000-2800 m. Alternatively, the present water depths at ODP Sites $794(2800 \mathrm{~m})$ and $797(2864 \mathrm{~m})$ in the Yamato Basin and ODP Site $795(3300 \mathrm{~m})$ in the Japan Basin are considered to be the maximum water depths to which these locations have subsided (Figs. 1 and 2).

Several recent reports have proposed that the dominantly or exclusively agglutinated benthic foraminiferal faunas found within lower and middle Miocene deposits in the Japan Sea area may represent abyssal water depths exceeding $3000 \mathrm{~m}$. In particular, Guber and Merrill (1983) propose that the agglutinated benthic foraminiferal assemblages found in middle Miocene strata of the Hokuroku area of northern Honshu, Japan (Fig. 1), are indicative of water depths of $3500-4000 \mathrm{~m}$ based upon analogy with faunas found below the calcium carbonate compensation depth (CCD) in the modern Pacific Ocean-despite the fact that this latter depth exceeds the average depth of the Japan Basin, the largest and deepest basin within the modern Japan Sea (Fig. 2). As discussed by Matoba (1983) and Nomura (this volume), the local CCD within the Miocene proto-Japan Sea was almost certainly shallower than the present depth of the CCD in the open Pacific Ocean. This circumstance reflects both the distinctive water masses formed in silled basins as well as differences in behavior of the Miocene ocean and climate (Berger, 1979). Of special interest, the local CCD in the modern Japan Sea is ca. 1800-2000 m and agglutinated foraminiferal faunas are dominant below this depth (Ichikura and Ujiie, 1976; Matoba and Honma, 1986). The CCD in the Japan Sea may have been even shallower during Pleistocene glacial maxima (Ujiie and Ichikura, 1973; Oba et al., 1991).

Specific foraminiferal evidence cited by Guber and Merrill (1983) in support of their interpretations of abyssal water depths for middle Miocene strata in northern Honshu includes the occurrence of exclusively agglutinated faunas marked by high abundances of Martinotiella communis. In fact, Martinotiella communis is known to be associated with the impingement of low oxygen intermediate water along the modern Pacific Coast of Japan with peak abundances present at depths of 300-700 m (Kaiho and Hasegawa, 1986). Moreover, dominantly to exclusively agglutinated foraminiferal faunas characterized by species of Ammodiscus, Bathysiphon, Cribrostomoides, Glomospira, Lagenammina, Thalmannammina, Trochammina, and Silicosigmoilina occur at depths as shallow as $1800 \mathrm{~m}$ in the modern Japan Sea as a consequence of the elevated CCD (Matoba and Honma, 1986; Akimoto and Hasegawa, 1989). Thus, analogy with Recent benthic foraminiferal biofacies distributions around the Japanese Islands suggests that the Miocene sub-basins which formed along the rim of the evolving Japan Sea likely subsided to maximum water depths between 2000 and $3000 \mathrm{~m}$ (Matoba, 1983) but did not reach abyssal depths of $4000 \mathrm{~m}$.

Geophysical considerations also offer constraints on maximum water depths attained in the Miocene sub-basins of the Japan Sea area. The hypsometry of the modern world ocean emphasizes that water depths in areas underlain by continental and quasi-continental (transitional) crust are invariably shallower than $2500-2800 \mathrm{~m}$ whereas areas of ocean floor underlain by oceanic crust routinely display water depths in excess of $3000 \mathrm{~m}$ save for active mid-ocean ridge crests. These latter relationships presumably reflect the basic differences in composition, densities, thickness, and in turn differential subsidence capacities of continental vs. oceanic crust.

Geophysical and geologic data demonstrate that the Japanese Islands and associated volcanic arcs are underlain by continental crust (Yoshii and Asano, 1972). Thus, it seems reasonable to assume that the many Miocene sub-basins which formed within the evolving island complex and inner arc areas of the eastern Japan Sea experienced subsidence to water depths no deeper than 2500-2800 m, commensurate with their formation in areas underlain by continental crust. Because many of the Miocene sub-basins now exposed in northern Honshu (e.g., the Hokuroku basin) were apparently formed as intra-crustal or so-called failed-rifts on the flanks or within the Northeast Japan Arc (Ohmoto and Skinner, 1983), it is instructive to note that the modern Kita-Yamato Trough, a failed-rift of similar scale within the Yamato Rise of the central Japan Sea (Fig. 1), has a maximum water depth of $2200 \mathrm{~m}$ which is in line with the granitic basement underlying this feature. Alternatively, vigorous backarc spreading of oceanic crust in the Japan Basin (Tamaki et al., this volume) allowed subsidence to water depths of $3000-3500 \mathrm{~m}$ (Fig. 2).

\section{RESULTS AND DISCUSSION OF SUBSIDENCE ANALYSIS}

\section{Onshore Sections and Offshore Wells}

Onshore surface and subsurface Neogene deposits located along the southern and eastern margins of the Japan Sea provided the bulk of pre-ODP stratigraphic evidence regarding the timing and character of its subsidence. Important Neogene surface sections are located; (1) in northern and southern Sakhalin, (2) at Wakkanai, Enbetsu, Hidaka, and the Oshima Peninsula on Hokkaido, (3) within the Ou Backbone Ranges and in the Shimokita, Oga Peninsula, Noto Peninsula, Himi, and San'in areas of Honshu, (4) on Sado Island and the Oki and Tsushima islands, and (5) in the southeastern and northeastern coastal areas of the Korean Peninsula (Tsuchi and IGCP-114 National Working Group of Japan, 1981; Fig. 1). The best studied of these sequences are located north of the Fossa Magna in the central and western areas of northern Honshu (Fig. 1) and have been the subject of major syntheses of Neogene biostratigraphy, lithostratigraphy, tectonics, and basin history by Tsuchi (1981a,b), Kitamura et al. (1989), Iijima et al. (1988), Yamaji and Sato (1989), and Iijima and Tada (1990). Some of the margin sub-basins in these latter areas are filled with over $6000 \mathrm{~m}$ of Neogene sediment in contrast to the relatively less sedimented deep basins of the Japan Sea proper which contain 1500$3000 \mathrm{~m}$ of Neogene sediment (Tamaki, 1988).

Despite differences in geometry and location, the majority of the onshore Neogene sequences in the Japan Sea region exhibit similar depositional histories marked by the widespread occurrence of middle and upper Miocene bathyal diatomaceous deposits (e.g., Ingle, 1975, 1981; Iijima et al., 1988). The ubiquity of these bathyal units has been commonly cited as key evidence that the initial, rapid subsidence of the Japan Sea occurred in early middle Miocene time ca. 16-15 Ma. However, the presence of lower Miocene bathyal deposits in some surface sections along the 
eastern margin of the Japan Sea (e.g., Takayama, 1977; Ikebe and Maiya, 1981; Kim, 1990; Sato et al., 1991) indicates that earlier rapid subsidence and marine flooding occurred in some areas-a pattern clearly substantiated by ODP drilling (Tamaki, Pisciotto, Allen, et al., 1990; Ingle, Suyehiro, von Breymann, et al., 1990) and implied by the subsidence analysis of the Dolgorae-1 Well in the Tsushima basin (Chough and Barg, 1987).

Although poorly known, the Giji-Myeoncheon surface section in the northeastern corner of the Korean Peninsula (Fig. 1) is of special significance because of its location west of the Japan Basin. This section apparently displays the same Neogene depositional history and lower Miocene volcanic units as established within the better studied sequences exposed on the southern Korean Peninsula, Honshu, Hokkaido, and Sakhalin (Kim, 1977; Lee and Pouclet, 1988). In fact, biostratigraphic studies of samples dredged from submarine exposures of Neogene sediment along the continental slope off Siberia provide concrete evidence (Tsoy, 1988) that the entire western margin of the Japan Sea experienced a similar if not identical pattern of Miocene subsidence and deposition to that established for the eastern and southern margins of the sea.

Based on their locations at the southern, eastern, and northern margins of the Japan Sea and the availability of stratigraphic and microfaunal data with which to interpret their chronostratigraphy and paleoenvironmental history, three key surface sections were selected for quantitative subsidence analysis. The Pohang section is located at the southeastern corner of the Korean Peninsula and chronicles Neogene subsidence along the southern margin of the Japan Sea (Fig. 1). The Oga Peninsula section is exposed on northwestern Honshu Island, Japan and documents Neogene subsidence along the western flank of the Tohoku Arc (Fig. 1). The southern Sakhalin or Makarov River section illustrates Neogene subsidence along the northern margin of the Japan Sea in an area influenced by events in both the Japan and Kurile Basins (Fig. 1). Finally, results from an earlier subsidence analysis of the offshore Dolgorae-1 Well on the southern margin of the Tsushima basin (Chough and Barg, 1987) constrain Neogene events in this area of the sea (Fig. 1).

\section{Oga Peninsula Section}

The Oga Peninsula section has long been considered the most important Neogene reference section for the Japan Sea region as a whole and encompasses a remarkably complete record of the subsidence, filling, and deformation of a sub-basin formed along the eastern margin of the sea as displayed in over $4000 \mathrm{~m}$ of Oligocene through Pleistocene volcanic rocks and sediments (Fig. 4). The oldest basement rock exposed on the Oga Peninsula is Paleocene granite (Matoba et al., 1990) suggesting the presence of rifted continental crust beneath this area. Isopach maps and regional basin studies illustrate that the Oga Peninsula sequence typifies the pattern of deposition and subsidence exhibited by many of the small Neogene sub-basins formed along the western margin of northern Japan (Iijima et al., 1988; Iijima and Tada, 1990; Hashimoto, 1991, p. 228).

The extensive lithostratigraphic, biostratigraphic, and geochronologic data available for the Oga Peninsula section have been summarized by Kitazato (1975), Takayasu and Matoba (1976), and Matoba et al. (1990). The regional value of the Oga Peninsula section has been further enhanced by intensive study of correlative Neogene subsurface sequences in the adjacent Akita and Niigata basins (Matsunaga, 1963; Maiya, 1978; Ikebe and Maiya, 1981) and other important surface sections exposed along the western coast of Honshu and Hokkaido (Tsuchi, 1981a,b; Ogasawara et al., 1991) and Hokkaido (Fig. 1).

Age control within the Oga Peninsula sequence is excellent. Biostratigraphic studies of planktonic foraminifers, calcareous nannoplankton, and diatoms allow recognition of global and regional planktonic datums and in turn correlation with the magnetic polarity and radiometric time scales (Tsuchi et al., 1981; Oda, 1986: Matoba et al., 1990). Additional age control in this sequence is provided by magnetostratigraphic studies and radiometric dating of volcanic units (Kent, 1973; Kimura, 1986; Kitazato, 1975; Suzuki, 1980; Ganzawa, 1983, 1987).

Paleoenvironmental and paleobathymetric assignments for the Oga Peninsula section (Fig. 4) are based primarily on the distribution of benthic foraminifers reported from this sequence by Fukasawa (1990) and Matoba et al. (1990) and significant variations in lithofacies and sedimentary structure. These latter observations include laminated diatomaceous mudstone of the Onnagawa and Funakawa formations that record deposition beneath low oxygen water masses and the repetitive sand/silt packages of the Kitaura Formation indicative of submarine fan and base-of-slope deposition (Matoba et al., 1990).

Two plots illustrate the subsidence and uplift history recorded by the Oga Peninsula section (Figs. 5 and 6). A plot of decompacted burial history, paleobathymetry, and uncorrected rates of sediment accumulation and subsidence serves to emphasize the episodic nature of basin formation and destruction and the relation of depositional phases to discrete tectonic events (Fig. 5). A plot depicting paleobathymetry, tectonic (residual) subsidence, and total subsidence for this section clearly defines multiple extensional phases and an abrupt compressional phase marking the evolution of the Oga-Akita Basin (Fig. 6). This latter diagram represents the standard format used to illustrate the subsidence histories of all sequences analyzed.

Suzuki (1980) reports a fission track date of $31.5 \mathrm{Ma}$ in the lower Monzen Formation of the Oga area, just above the basal unconformity separating this unit from the underlying Paleogene basement rocks (Fig. 4). This date sets a lower limit on the age of incipient rifting, extension, and subsidence in the Oga inner arc area coincident with the eruption and deposition of the widespread "Green Tuff" lithofacies characterizing the earliest phases in the evolution of the Japan Sea (Iijima and Tada, 1990). The residual or tectonic subsidence curve records relatively slow subsidence during Monzen syn-rift deposition compatible with initial crustal thinning and thermal decay (Fig. 6). Although almost $1000 \mathrm{~m}$ of upper Oligocene volcanic flow rocks, pyroclastic, and non-marine sediment were deposited during Monzen time, the rate of subsidence apparently exceeded the rate of sediment accumulation throughout this period (Fig. 5).

An unconformity also separates the Monzen Formation from the overlying sequence of lower Miocene pyroclastic, basalt, and nonmarine terrestrial and lacustrine sediment assigned to the Daijima Formation (Fig. 4). Available radiometric dates immediately above and below this latter unconformity indicate that it spans an age of 23-22 Ma (Ganzawa, 1983; Matoba et al., 1990). Tectonically induced subsidence slowed during Daijima time (Fig. 6) with rates of sediment accumulation approximately equal to rates of subsidence over a period of some 7 m.y.

Initial Neogene marine deposits in the Oga Peninsula section are represented by fossiliferous littoral and shelf deposits of the Nishikurosawa Formation (Fig. 4). The oldest planktonic foraminifers found to date in this formation are indicative of zone N8 (Matoba et al., 1990) indicating marine flooding of this area commenced ca. 16-15 Ma in concert with a dramatic acceleration of tectonically driven subsidence (Fig. 6), an event responsible for the formation of the Oga-Akita Basin as well as other sub-basins along the margins of the Japan Sea (Iijima and Tada, 1990). Maximum rates of subsidence during this latter period exceeded $900 \mathrm{~m} / \mathrm{m}$.y., outpacing sediment accumulation, and in turn leading to relative starvation of the ensuing deep basin which reached a depth of 2000 to possibly 2800 $\mathrm{m}$ (Figs. 4, 5, and 6). A previous backstripping analysis of subsurface sections in the Niigata Basin (Hoshi, 1988) illustrates that a coincident episode of rapid early middle Miocene tectonic subsidence and basaltic magmatism also occurred in this area.

Significantly, pelagic and hemipelagic diatomaceous muds are the dominant sediment types during middle and late Miocene time due in part to the low influx of diluting terrigenous clastics to the newly created Oga-Akita Basin during this period (Fig. 5). The short dura- 


\section{OGA PENINSULA, JAPAN}

Ma SERIES FORMATION

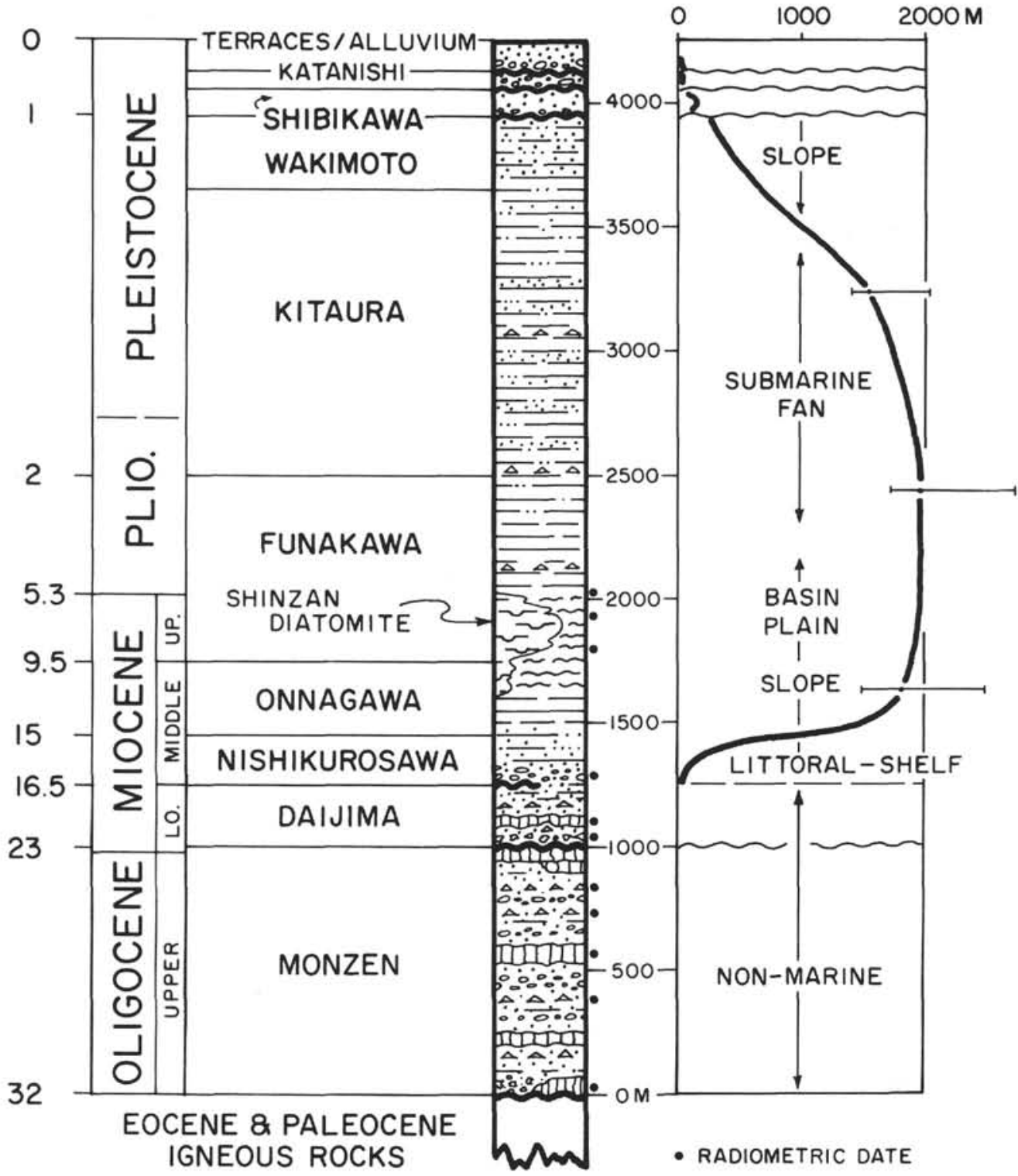

\section{P:요 SILTSTONE \\ $\begin{array}{ll}\Delta \Delta \text { DIATOMITE } & \text { TUFF } \\ \text { Bage vOLC. BRECCIA }\end{array}$ \\ $\therefore \therefore$ SANDSTONE

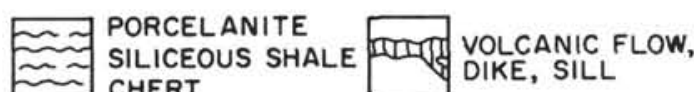

Figure 4. Stratigraphy, depositional environments, and paleobathymetry of the Oga Peninsula section, northwestern Honshu, Japan (see Fig. 1 for location). Note that the Shinzan Diatomite and genetically related porcellanites are defined as a distinctive lithofacies present within both the Funakawa and Onnagawa formations. Lithologies are highly generalized and maximum reported thicknesses of each formation are depicted. See text for sources of data. 


\section{OGA PENINSULA}

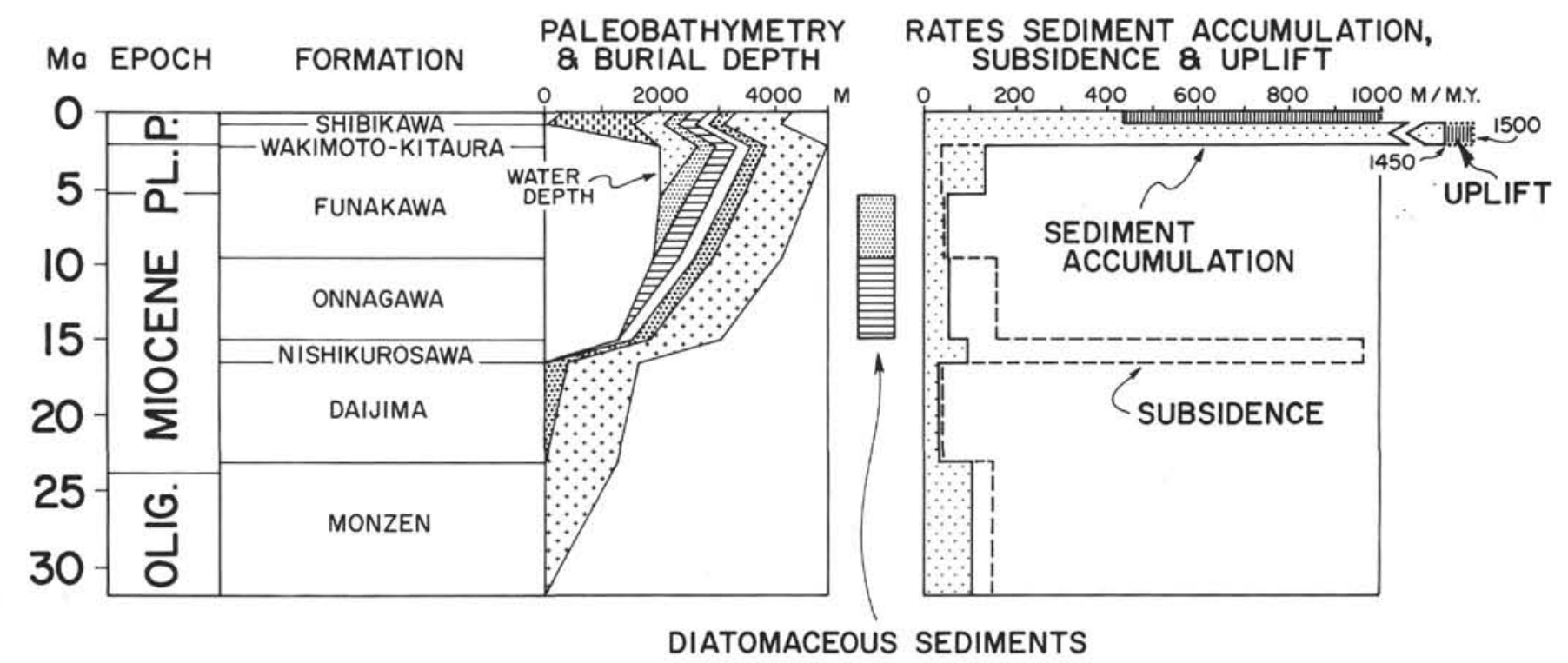

Figure 5. Backstripped burial history, paleobathymetry, and uncorrected rates of sediment accumulation, subsidence, and uplift for the Oga Peninsula section, northwestern Honshu, Japan (see Fig. 1 for location).

tion and high rates of tectonic subsidence marking the 16-15 Ma event argue for a period of normal faulting and pull-apart basin formation as described by Pitman and Andrews (1985). This process involved lithospheric stretching and rapid lateral loss of heat that induces extremely rapid subsidence and consequent initial basin starvation. Paleomagnetic data imply that ca. 15 Ma southwest Japan experienced $45^{\circ}$ of clockwise rotation with fully $80 \%$ of this motion occurring between 16 and $14 \mathrm{Ma}$ (Otofuji et al., 1991). This event is commonly linked to rapid middle Miocene extension and subsidence of the Japan Sea (Otofugi and Matsuda, 1983, 1987; Otofuji et al. 1985, lijima et al., 1988; Tamaki, 1988; Hirooka et al., 1990; Hayashida,

\section{OGA PENINSULA}

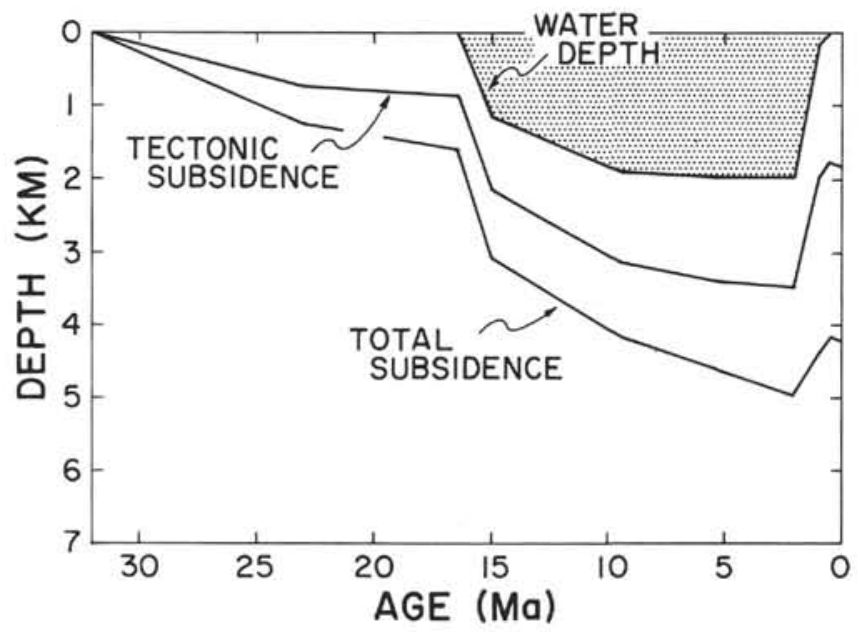

Figure 6. Backstripped subsidence plot of the Oga Peninsula section illustrating paleobathymetry and tectonic (residual) and total components of vertical motion (e.g., subsidence and uplift) experienced by this sequence over the past 32 m.y. assuming local Airy isostasy. et al., 1991) as illustrated by the Oga Peninsula section (Fig. 6). However, the results of ODP drilling in the Japan and Yamato basins (Tamaki, Pisciotto, Allen, et al., 1990; Ingle, Suyehiro, von Breymann, et al., 1990) clearly show that the early middle Miocene episode of rapid subsidence of margin sub-basins, including the Oga-Akita and Niigata basins, post-dates the major late Oligocene-early Miocene subsidence and formation of the major deep basins of the Japan Sea. Rather, the formation of middle Miocene sub-basins around the margins of the sea appears to be the result of a second intense episode of backarc basaltic magmatism (Tsuchiya, 1990) and associated extension and propagation of rifts into the arc region and other peripheral areas of previously weakened continental crust. The culmination of this latter series of events is dramatically marked by the appearance of metalliferous hydrothermal deposits in a number of failed- or intra-crustal rifts as exemplified by the massive sulfide ores of the Hokuroku district (Ohmoto and Skinner, 1983; Fig. 1).

Local evidence of a pull-apart origin for many of the middle Miocene sub-basins formed along the eastern margin of the Japan Sea includes the fact that high-angle normal faults routinely define individual basins (Ohmoto, 1983). Finally, a pull-apart origin for this phase of backarc basin formation also fits well with the proposed initiation of strike-slip faulting along the eastern margin of the Japan Sea as a function of lithospheric breakup and backarc spreading in late early Miocene time (Jolivet and Tamaki, this volume). As noted earlier, Neogene sequences present along the western margin of the Japan Sea (e.g., the Giji-Myeongcheon section; Fig. 1) document that margin sub-basins also formed in early middle Miocene time in this area.

Late Miocene deep basin history in the Oga area is characterized by relatively low rates of subsidence and sediment accumulation ( 50 $\mathrm{m} / \mathrm{m}$.y.) apparently driven only by isostatic loading effects (Figs. 5 and 6). This pattern was terminated ca. $5 \mathrm{Ma}$ by an increasing influx of terrigenous clastics that diluted diatomaceous sediment and heralded the subsequent appearance of massive fan and base-of-slope deposits in Pliocene time (Fig. 5).

The sign of the Oga tectonic curve abruptly changes ca. $2 \mathrm{Ma}$ (Fig. 6) marking the initiation of rapid uplift in this area and a fundamental change from an extensional to a compressive tectonic regime. Uplift, 
together with increasing rates of sediment accumulation, resulted in the filling of the Oga-Akita Basin by late Pleistocene time (Figs. 4 and 5). Rates of uplift during this phase of basin history exceed 1000 $\mathrm{m} / \mathrm{m} . \mathrm{y}$. In addition, three angular unconformities in the upper Pleistocene part of the Oga Peninsula section express periods of accelerated compressive deformation (Fig. 4). This latter deformation apparently occurred in response to a newly evolving plate boundary in this region (Tamaki and Honza, 1985) and affected the entire eastern margin of the Japan Sea. Neogene basins to the east of the Oga area (e.g., Yokote-Shinjo Basin, Ou Backbone Ranges, etc.; Fig. 1) were affected by even earlier uplift and deformation, which began ca. $5 \mathrm{Ma}$ in latest Miocene-early Pliocene time (Tanimura et al., 1983).

\section{Pohang Section}

The Neogene Pohang Basin is located along the southeastern coast of the Korean Peninsula and represents an uplifted and deformed part of the larger offshore Tsushima (Ulleung) Basin (Figs. 1 and 2). About $3500 \mathrm{~m}$ of lower Miocene through Pleistocene sediment and volcanic rocks are exposed in the Pohang area and provide important information on the subsidence, depositional, and paleoceanographic history of the southern Japan Sea (Fig. 7). Exploration wells drilled in the Pohang area provide additional insights into basin evolution (e.g., Kim and Choi, 1977; Kim, 1990).

Basement rocks beneath the Pohang section include Cretaceous granite (Chang, 1977) and the basin is assumed to be underlain by extended continental crust. Over half of the Pohang sequence is composed of lower Miocene non-marine sediment and volcanic rocks deposited during initial rifting. Only $1100 \mathrm{~m}$ of middle Miocene through Pleistocene marine sediment represent the most dynamic phases of basin subsidence (Figs. 7 and 8). In contrast, approximately $10,000 \mathrm{~m}$ of lower Miocene through Pleistocene marine sediment were apparently deposited in an adjacent area of the southern Tsushima (Ulleung) Basin as described by Chough and Barg (1987).

The basic lithostratigraphy and depositional history of the Pohang sequence have been described by Um et al. (1964), Kim (1965), Yoon (1975), and Reedman and Um (1975). More recently, Chough et al. (1990) provided a detailed description and interpretation of the Neogene fan-delta system which filled the Pohang Basin during Miocene time. Aspects of the sedimentology and diagenesis of Miocene diatomaceous pelagic and hemipelagic deposits within the Pohang sequence are discussed by Garrison et al. (1979).

Ages within the marine part of the Pohang section are reasonably well constrained by siliceous microfossils (Lee, 1975, 1984; Koh, 1986; Ling et al., 1988), planktonic foraminifers (Kim, B. K., 1965, 1970, 1977, 1988; Kim, W. H., 1990), and resultant biostratigraphic correlations with the magnetostratigraphic and radiometric time scales. Additional local and provincial control is provided by mollusks (Yoon, 1975), benthic foraminifers (Kim, 1965, 1977, 1970; Yoo, 1969; Kim and Choi, 1977), and palynology (Bong, 1984). Age control in the lower Miocene non-marine part of the Pohang section is based primarily on radiometric dates on intercalated volcanic rocks (Lee and Pouclet, 1988).

Paleoenvironmental and paleobathymetric assignments for the Pohang section (Fig. 7) are based on the distribution and interpretation of benthic foraminifers reported from these sediments by Kim (1965) and Kim and Choi (1977) and sedimentologic evidence and interpretations presented by Garrison et al. (1979) and Chough et al. (1990).

Despite differences in thickness and tectonic setting, the Pohang section displays a similar Miocene depositional history to that of the Oga Peninsula section (Fig. 4) emphasizing the ubiquity of Neogene lithofacies patterns and subsidence events in the Japan Sea region. Early subsidence in the Pohang Basin is recorded by the thick syn-rift sequence of the Yangbuk Group which includes non-marine conglomerate, sand, coal, and volcanic rock similar in some respects to the Monzen Formation of the Oga Peninsula section (Figs. 4 and 6).

\section{POHANG, KOREA}

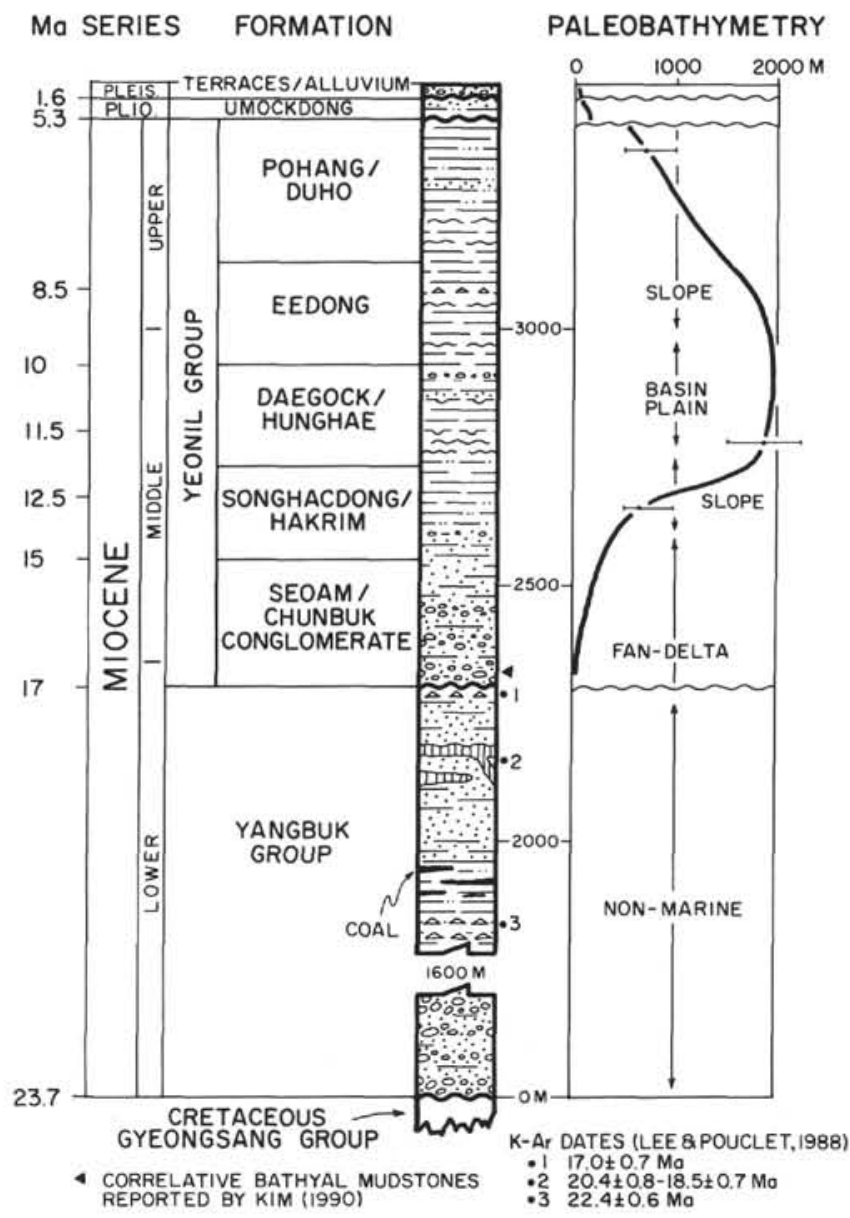

Figure 7. Stratigraphy, depositional environments, and paleobathymetry of the Pohang section, Korea (see Fig. 1 for location). Two sets of formational names are in use for some units included in the Yeonil Group as proposed independently by Kim (1965) and Reedman and Um (1975) hence two formational names are listed for these units on this column. Lower Miocene bathyal mudstones representing distal fan-delta slope deposits contiguous and correlative with the littoral and non-marine Chunbuk Conglomerate have recently been reported from a subsurface section drilled northeast of Pohang (Kim, 1990). Lithologies illustrated are highly generalized and maximum reported thicknesses of each formation are depicted on this column; lithologic symbols are explained on Figure 4. See text for sources of data.

Based on the oldest radiometric date available in this sequence (Lee and Pouclet, 1988), initial subsidence of the Pohang section was set at $23 \mathrm{Ma}$ on Figure 8 . However, more than $1800 \mathrm{~m}$ of terrigenous clastic deposits lie beneath this latter horizon (Fig. 7), suggesting that subsidence in the Pohang Basin almost certainly began earlier in late Oligocene time (ca. 30-25 Ma). Initial subsidence was thus coincident with subsidence recorded in other "Green Tuff" areas of the backarc region (e.g., Fig. 4). In any event, tectonically driven subsidence was well underway in the Pohang area by $23-20 \mathrm{Ma}$ (Fig. 8 ).

An angular unconformity separates the lower Miocene Yangbuk Group from the basal marine and non-marine fan-delta deposits of the overlying Yeonil Group. This discontinuity records an early Miocene episode of deformation in the Pohang area (Fig. 7). A radiometric date in the uppermost Yangbuk Group (Fig. 7), and planktonic foraminifers recorded from bathyal marine mudstone contiguous with the nearshore Seoam Conglomerate (Kim, 1990), 


\section{POHANG}

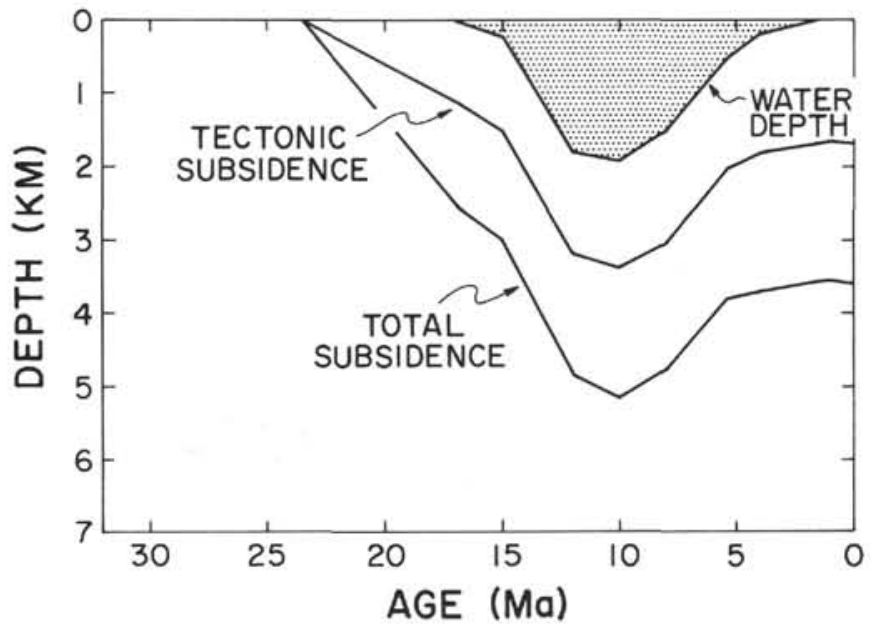

Figure 8. Backstripped subsidence plot for the Pohang section, Korea, with curves depicting paleobathymetric history and tectonic (residual) and total components of vertical motion assuming local Airy isostasy.

date the earliest marine sediment in the Pohang Basin at 18-17 Ma. Subsequent marine deposition records a rapid transition from neritic to upper bathyal water depths similar to events chronicled by the Nishikurosawa-Onnagawa sequence in the Oga Peninsula section (Fig. 4) and other onshore sequences around the margin of the Japan Sea.

Tectonic subsidence in the Pohang Basin accelerated to over $500 \mathrm{~m} / \mathrm{m} . \mathrm{y}$. by $13 \mathrm{Ma}$, and maximum water depths of $2000-2500 \mathrm{~m}$ were achieved by $12 \mathrm{Ma}$ (Fig. 8). Again, these rates and the short duration of the middle Miocene subsidence event suggest a pull-apart origin for this phase of basin history which is similar to the coeval episode of rapid subsidence recorded in the Oga Peninsula section (Fig. 6). Consequent basin starvation (Pitman and Andrews, 1985) is also evidenced by the appearance of pelagic and hemipelagic diatomaceous mudstone and genetically related porcellanite of the middle and upper Miocene Daegock and Eedong formations.

In contrast to continued late Miocene subsidence recorded in the Oga Peninsula section (Fig. 6), the Pohang Basin underwent pronounced uplift ca. $10 \mathrm{Ma}$ and was filled by sediment to upper bathyal-neritic depths by latest Miocene time (Fig. 8). Angular unconformities mark final deformational events, which elevated the Pohang sequence to neritic depths in Pliocene time and subsequently exposed these deposits during Pleistocene time (Figs. 7 and 8).

\section{Southern Sakhalin Section}

Deformed Neogene non-marine through bathyal marine deposits are exposed in the coastal and interior areas of Sakhalin Island and record tectonic and depositional events along the northern margin of the Japan Sea (Fig. 1). The Makarov River area in southern Sakhalin contains one of the most complete Neogene sequences and is considered a reference section for this region (Salnikov et al., 1979). Upper Oligocene through Pleistocene sediment totals over $6000 \mathrm{~m}$ in thickness in this area as described by Salnikov et al. (1979; Fig. 9). Gladenkov (1980) illustrates a generalized Oligocene-Pliocene column for the southern Sakhalin area that is more than $7000 \mathrm{~m}$ thick. This section records major Neogene subsidence and uplift during evolution of the Japan Sea and the adjacent Kurile Basin (Figs. 1 and 2). The stratigraphy of the southern Sakhalin sequence is similar to the Neogene sequences exposed on the Oshima Peninsula and in the Haboro-Enbetsu area of western and northern Hokkaido as described by Maiya et al. (1981) and Saito (1981), respectively (Fig. 1).
Upper Oligocene through Pliocene sediment in the southern Sakhalin-northern Hokkaido region displays two distinct cycles of subsidence and uplift involving late Oligocene-early Miocene and middle Miocene-Pliocene episodes of marine deposition separated by an abrupt period of uplift and subaerial exposure during early middle Miocene time (Figs. 9 and 10). Basement rocks underlying the northern Hokkaido-southern Sakhalin Neogene deposits include Paleogene and Cretaceous sediment that in turn overlie or are in fault contact with a complex of high-pressure metamorphic and ophiolitic rocks commonly assigned to the Kamuikotan-Ishikari belt (Hashimoto, 1991, p. 45).

The generalized lithostratigraphy illustrated for the southern Sakhalin sequence (Fig. 9) is a composite of descriptions given by Serova (1978), Salinkov et al. (1979), and Gladenkov (1980). It is also important to note that the southern Sakhalin area is still undergoing basic lithostratigraphic and biostratigraphic study and that the term suite is used in place of more formal formation names for distinct lithologic packages (Gladenkov, 1980, 1984a, 1990; Gladenkov and Shantser, 1990; Fig. 9).

Age control within the southern Sakhalin (Makarov River) sequence follows the biostratigraphic assignments of Gladenkov (1980, 1984b), Serova (1978), and Serova et al. (1981). These assignments are based on mollusks, planktonic and benthic foraminifers, and

\section{SOUTHERN SAKHALIN}

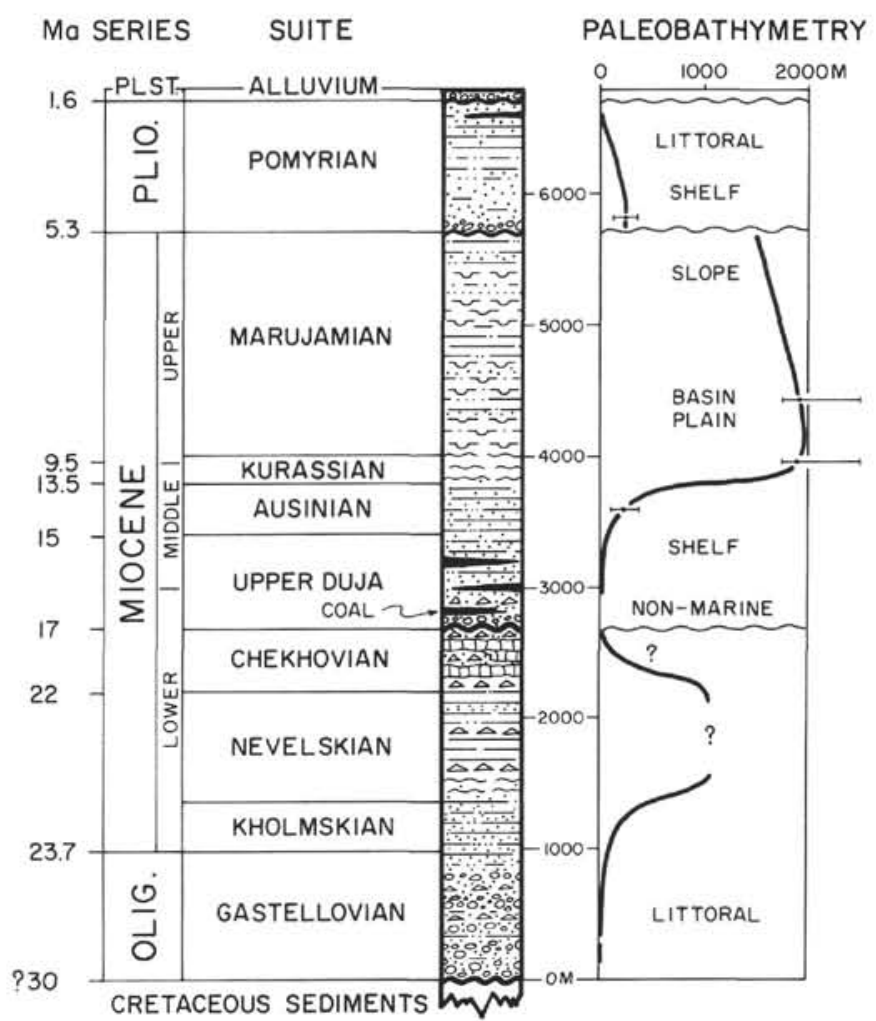

Figure 9. Stratigraphy, depositional environments, and paleobathymetry of the southern Sakhalin Island sequence, Russia, based primarily on data reported from the Makarov River area (see Fig. 1 for location). Note that the term "suite" is used in place of formation following the custom and definitions of local workers (e.g., Salnikov et al., 1979). The paleobathymetric and paleoenvironmental history of the Kholmskian, Nevelskian, and Chekhovian suites is poorly constrained due to lack of detailed benthic foraminiferal data. Lithologies are highly generalized and maximum reported thicknesses are depicted for each suite; lithologic symbols are explained on Figure 4. See text for sources of data. 


\section{SOUTHERN SAKHALIN}

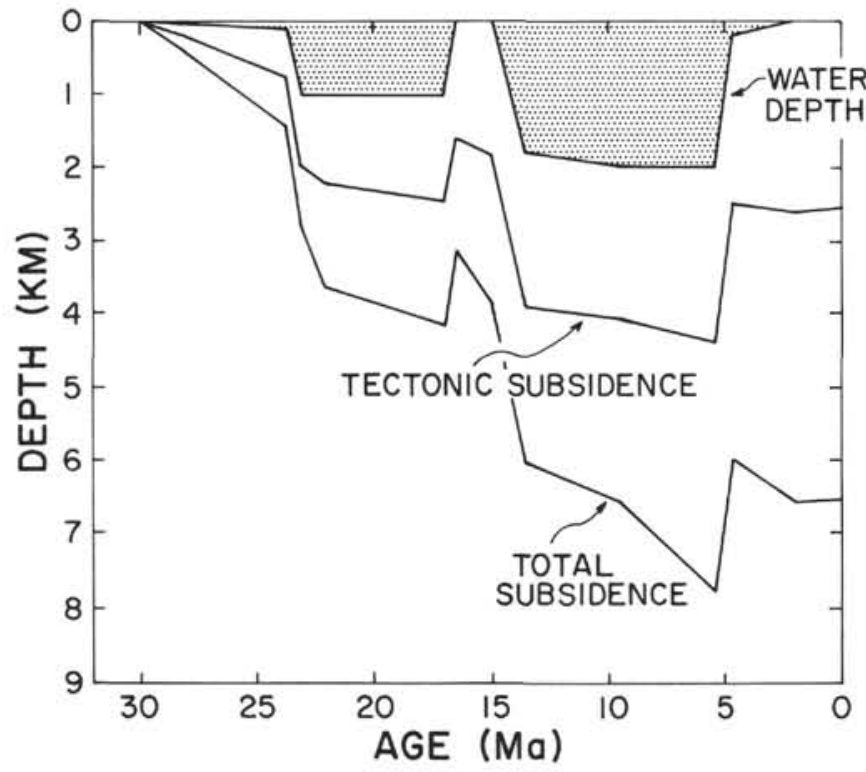

Figure 10. Backstripped subsidence plot for the southern Sakhalin (Makarov River) section, Sakhalin Island, Russia, with curves illustrating paleobathymetric history and tectonic (residual) and total components of vertical motion assuming local Airy isostasy.

diatoms together with radiolarian evidence presented by Tochilina (1986) and Tochilina et al. (1988). Because biostratigraphic studies of this sequence are still in progress, the general age assignments given in this report are subject to change. However, general correlation with the Neogene sequences of Hokkaido suggests that ages assigned to the Miocene parts of the southern Sakhalin sequence are correct with the greatest uncertainties attached to ages assigned to the Oligocene and Pliocene sections of the column (Fig. 9).

Paleobathymetric and paleoenvironmental assignments for the southern Sakhalin sequence are based primarily on interpretation of benthic foraminiferal assemblages reported from these deposits by Serova (1978). Additional information is provided by lithologic and sedimentologic evidence described by Salinkov et al. (1979) and characteristic molluscan assemblages reported by Gladenkov (1984a,b). Lack of detailed benthic foraminiferal evidence from the lower Miocene part of the sequence prevents firm paleobathymetric assignments for the bathyal deposits within the Nevelskian suite (Fig. 9). Nevertheless, benthic foraminiferal assemblages common in correlative and lithologically similar units in the adjacent Enbetsu area of Hokkaido (Saito, 1981) suggest that water depths likely reached $1000 \mathrm{~m}$ or deeper during Nevelskian time (Fig. 9).

Subsidence in the southern Sakhalin area began in the late Oligocene with deposition of almost $1000 \mathrm{~m}$ of littoral conglomerate and sand in contrast to the widespread deposition of non-marine "Green Tuff" syn-rift units in the central and southern backarc areas (e.g., Fig. 4). This latter event was followed by an episode of rapid tectonically driven subsidence beginning ca. $23 \mathrm{Ma}$ accompanied by increasing accumulation of volcaniclastic deposits (Figs. 9 and 10). Equally rapid uplift in the southern Sakhalin area occurred ca. 19-17 Ma, coincident with the appearance of abundant volcanic flow rocks, and is highlighted by an erosional unconformity and deposition of non-marine and littoral deposits during upper Duja time (Fig. 9). The late early Miocene episode of uplift in southern Sakhalin stands in contrast to the common pattern of subsidence during this period in the central and southern areas of the Japan Sea (e.g., Fig. 6). This circumstance suggests that the southern Sakhalin area may have briefly acted as a hinge during arc rotation and/or crustal extension. Alternatively, this latter event may express transpressional deformation caused by strike-slip motion along the Sakhalin margin as envisioned by Jolivet et al. (1991) and Jolivet and Tamaki (this volume).

Middle Miocene and upper Miocene subsidence and depositional history in the southern Sakhalin area are similar to those recorded elsewhere in the Japan Sea. An episode of abrupt and rapid subsidence commenced in the early middle Miocene ca. 15 Ma with water depths of 2000-2500 m achieved by $13 \mathrm{Ma}$. This event was accompanied by the deposition of middle and upper Miocene pelagic-hemipelagic diatomaceous deposits and diagenetically produced porcellanites, typical of Neogene sequences throughout the Japan Sea region (e.g., Iijima et al., 1988). Both the $23 \mathrm{Ma}$ and $15 \mathrm{Ma}$ subsidence events appear to represent rapid fault-assisted production of discrete pullapart basins that in each area ended with slow isostatic subsidence caused by minimal sediment loading (Fig. 10). Abrupt uplift terminated both episodes of subsidence at $17 \mathrm{Ma}$ and $5 \mathrm{Ma}$, respectively.

\section{Dolgorae-1 Offshore Well}

A number of offshore exploration wells have been drilled along the southern margin of the Tsushima (Ulleung) basin in the shelf region west of Honshu and in the Tsushima Strait (Fig. 2). Chough and Barg (1987) present stratigraphic columns for six of these wells and use age, lithologic, and paleobathymetric data from the Dolgorae1 Well to construct a quantitative subsidence history using the backstripping technique (Figs. 1 and 11). The Dolgorae-1 Well penetrated $4265 \mathrm{~m}$ of lower Miocene through Pleistocene marine sediment. However, Chough and Barg (1987) note that acoustic basement in this area occurs at a depth of about $10 \mathrm{~km}$ and they consequently place the base of the Neogene sediment column at this depth (Fig. 11).

Benthic foraminifers were used to estimate paleobathymetry in the Dolgorae-1 sequence (Chough and Barg, 1987) with a maximum water depth ca. $1800 \mathrm{~m}$ achieved during middle Miocene time (Fig. 11). A late Miocene angular unconformity separates the Miocene slope-toshelf sequence from overlying Pliocene and Pleistocene neritic units in the Dolgorae-1 Well. Adjacent wells and seismic reflection profiles demonstrate the regional extent of this unconformity (Honza et al., 1979; Tamaki, 1988), which also separates Miocene and Pliocene units in the Pohang section $100 \mathrm{~km}$ to the northwest (Fig. 7).

Chough and Barg (1987) set the initiation of subsidence in the Dolgorae-1 sequence at $28 \mathrm{Ma}$, in line with widespread evidence of late Oligocene-early Miocene syn-rift deposition elsewhere around the perimeter of the Japan Sea (Figs. 4, 7, and 11). Backstripping analysis indicates that initial tectonic subsidence proceeded at a rate of ca. 300 $\mathrm{m} / \mathrm{m}$.y. comparable to rates of concurrent subsidence recorded in the Pohang area (Figs. 7 and 11). Tectonic subsidence subsequently slowed in the middle Miocene and was terminated when uplift commenced ca. 11 Ma culminating in deformation of basin-fill units and creation of the regional late Miocene (9-8 Ma) unconformity.

\section{ODP Sites}

Four of the six ODP sites drilled in the Japan Sea are in basinal locations and provide multiple evidence of deposition and subsidence in contrasting crustal settings. Site 795 is in the northern Japan Basin and underlain by oceanic crust. Sites 794 and 797 are in the Yamato Basin and underlain by extended continental crust (Hamano et al., 1989; Tamaki et al., this volume). Site 799 is located in the KitaYamato Trough within the larger Yamato Rise and represents a failedor intra-crustal rift setting within a tectonically isolated fragment of continental crust (Ingle, Suyehiro, von Breymann, et al., 1990; Figs. 1,2 , and 12). Drilling at all four sites penetrated Pleistocene through lower Miocene sediments; basalt and dolerite units were cored at the base of the Neogene columns at Sites 794, 795, and 797 (Fig. 12). Despite fundamental differences in tectonic/crustal settings, evidence from the basal sediment at Sites 794, 795, 797, and 799 indicates that the Japan and Yamato basins, as well as the Kita-Yamato Trough, had 


\section{DOLGORAE-I WELL}

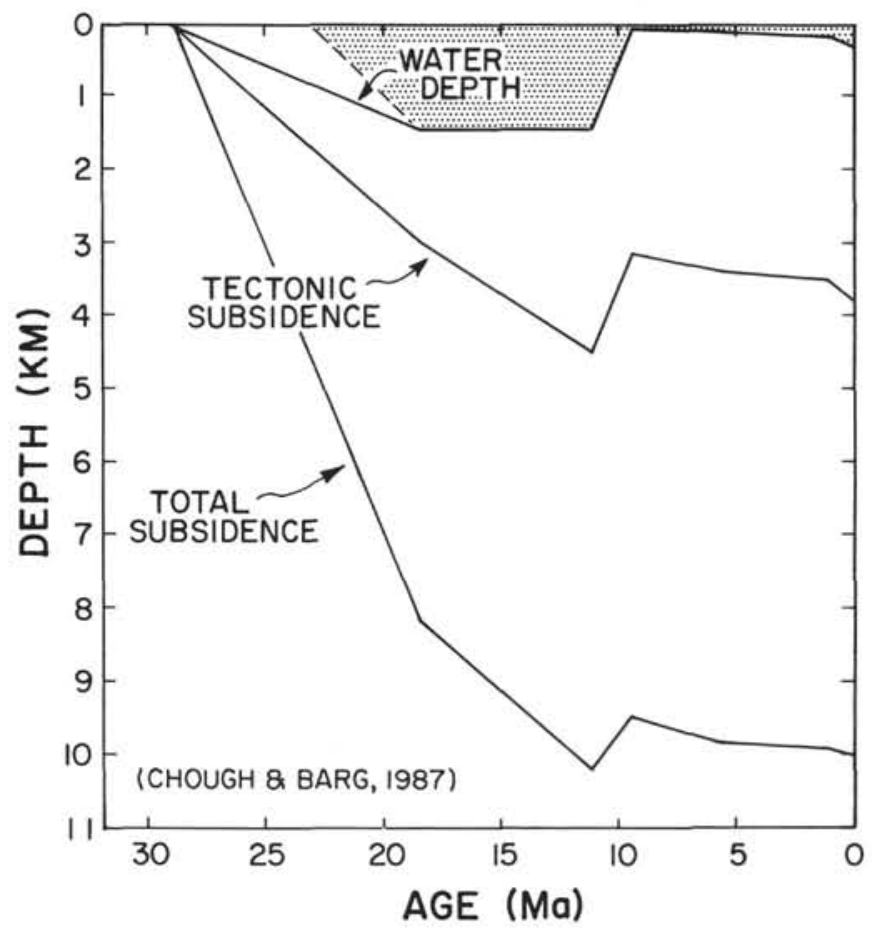

Figure 11. Backstripped subsidence plot of the stratigraphic column penetrated in the Dolgorae-1 Well in the southern Japan Sea (Tsushima Basin) as analyzed by Chough and Barg (1987). Curves depict paleobathymetry and tectonic (residual) and total components of vertical motion assuming local Airy isostasy. The dashed line illustrates the pattern of subsidence using the youngest possible age for initiation of this process (ca. $23 \mathrm{Ma}$ ) as opposed to the preferred age of $28 \mathrm{Ma}$.

subsided to middle or lower bathyal depths by early Miocene time (Fig. 12). As noted earlier, subsidence analysis indicates that the Tsushima Basin also subsided to lower bathyal depths by early Miocene time (Fig. 11). Thus, all three major basins of the Japan Sea were structurally and bathymetrically well defined by $20-18 \mathrm{Ma}$.

Alternatively, drilling at Site 796 on the Okushiri Ridge and Site 798 on the Oki Ridge yielded evidence that these features were significantly uplifted in late Pliocene and Pleistocene time (Fig. 12) coincident with the onset of regional compressive deformation along the eastern margin of the Japan Sea.

Age control within the six ODP sites ranges from poor to excellent and is variously constrained by magnetostratigraphy (Brumsiek, this volume) and both siliceous and calcareous plankton. This information is summarized by Burckle et al. (this volume) and detailed in individual reports presented in this volume by Alexandrovich, Brunner, Burckle, Kheradyar, Koizumi, Ling, Muza, and Rahman. Analyses of spore and pollen (Yamanoi, this volume) and benthic foraminifers (Nomura, this volume) provide additional biostratigraphic control. Diatoms and magnetostratigraphy provide well constrained ages in Pliocene and Pleistocene sediment at all sites but diagenetic effects reduce the quality and quantity of biostratigraphic ages established in sediment below the opal A-opal/opal CT boundary (Burckle et al., this volume). Nevertheless, biostratigraphic control is adequate enough to delimit or extrapolate the basal age of all six sediment columns sampled. Furthermore, radiometric ages determined for lower Miocene basalts cored at Sites 794, 795, and 797 constrain the ages of basement rocks flooring these areas of the Japan and Yamato basins (Kaneoka et al., this volume; Pouclet and Bellon, this volume). As discussed by Tamaki et al. (this volume), biostratigraphic ages determined for the sediment/basalt contacts at these latter three sites are 18-16 Ma at Site 794, 16.5-14.5 at Site 795, and 19-17 Ma at Site
797. The age ranges of the most reliable ${ }^{40} \mathrm{Ar}-{ }^{39} \mathrm{Ar}$ dates obtained on the underlaying basaltic rock are 21.2-19.9 Ma at Site 794, 23.7-17.1 $\mathrm{Ma}$ at Site 795, and 19.0-17.7 Ma at Site 797 (Kaneoka et al., this volume).

The paleobathymetric curves illustrated for the six ODP Japan Sea sites (Figs. 12 and 13) are based on the interpretations of benthic foraminifers reported from these locations by Brunner (this volume), Kato (this volume), and Nomura (this volume). Most importantly, middle and lower Miocene strata at base of the Site 794, 795, 797, and 799 sequences all contain deep bathyal benthic taxa which offer unequivocal evidence that these beds were deposited at water depths within $500-1000 \mathrm{~m}$ of the present water depths at these sites (Fig. 12). Moreover, sediment intercalated with volcaniclastic and basaltic flow units at Sites 794 and 797 also contain deep bathyal benthic foraminifers (Fig. 12). Thus, the floors of the Japan, Yamato, and Tsushima basins had clearly reached middle to lower bathyal depths by ca. 20-18 Ma. as noted earlier (Figs. 11, 12, and 13). Significantly, early Miocene fresh and brackish water diatoms have been recovered from core and dredge samples from the flanks of the Yamato Rise adjacent to ODP Site 799 suggesting that large lakes occupied some of the earliest rift valleys in the backarc area prior to marine incursion and rapid subsidence (Koizumi, 1988). Clearly, the age of initial subsidence and marine flooding at ODP Sites 794, 795, 797, and 799 must predate the age of the oldest rocks sampled at these sites. Just when did initial subsidence commence in the deep basins of the Japan Sea?

A plot and correlation of paleobathymetric histories for ODP Sites 795 and 797, the Dolgorae-1 offshore well, and the Oga Peninsula and southern Sakhalin surface sections provide a north-south perspective of Neogene subsidence in the Japan Sea backarc basin (Fig. 13). This diagram emphasizes the evidence and implications that initial subsidence in all three major basins (e.g., the Tsushima, Yamato, and Japan basins) and the marginal sub-basins around the periphery of the Japan Sea occurred during late Oligocene-early Miocene time ca. $30-25 \mathrm{Ma}$. These records also illustrate that the early evolution of the sea involved simultaneous subsidence and deposition of non-marine syn-rift sequences in some areas and rapid spreading, extension, and creation of deep marine basins in other areas. This pattern of vertical tectonism is depicted in a set of paleogeographic maps recently presented by lijima and Tada (1990).

Consideration of all available stratigraphic, petrologic, and geophysical evidence both from ODP drilling and onshore and offshore studies suggests that the period of major extension, volcanism, and opening of the Japan Sea occurred between 28 and $18 \mathrm{Ma}$ (Tamaki et al., this volume). More specifically, lithostratigraphic, biostratigraphic, and radiometric evidence from onshore sections points to two episodes or phases of initial backarc subsidence in the Japan Sea region; (1) the late Oligocene-early Miocene Monzen period marked by widespread nonmarine and "Green Tuff" deposition beginning ca. 32-28 Ma and (2) the Daijima period ca. 24-17 Ma involving deformation and subsidence in the central and southern Japan Sea (Figs. 4, 7, and 9) and increasing volcanic activity throughout the Japan Sea and Japan Arc (e.g., Tsuchiya, 1990). In addition, the record of arc and backarc volcanism as determined by radiometric dating of both onshore and dredged volcanic rocks from the Japan Sea region indicates that the bulk of this material was produced between 25 and 17 Ma (Fujioka, 1986; Kaneoka, 1986, 1990).

Considering that lower bathyal water depths existed in the Tsushima, Yamato, and Japan basins by $20-18 \mathrm{Ma}$, and that widespread volcanism, deformation, and subsidence in the margin subbasins of the Japan Sea began ca. 24-23 Ma (Figs. 4, 7, 9, 12, and 13), a backstripped subsidence plot for ODP Site 794 was produced with initial subsidence set at $23 \mathrm{Ma}$ (Fig. 14), the youngest possible age for this event. ODP Site 794 constitutes a particularly useful deep basin reference because it is located at the geophysically defined juncture between the Yamato and Japan basins where occurrence of both oceanic and extended continental crust must have influenced subsidence (Ingle, Suyehiro, von Breymann, et al., 1990, p. 74). 

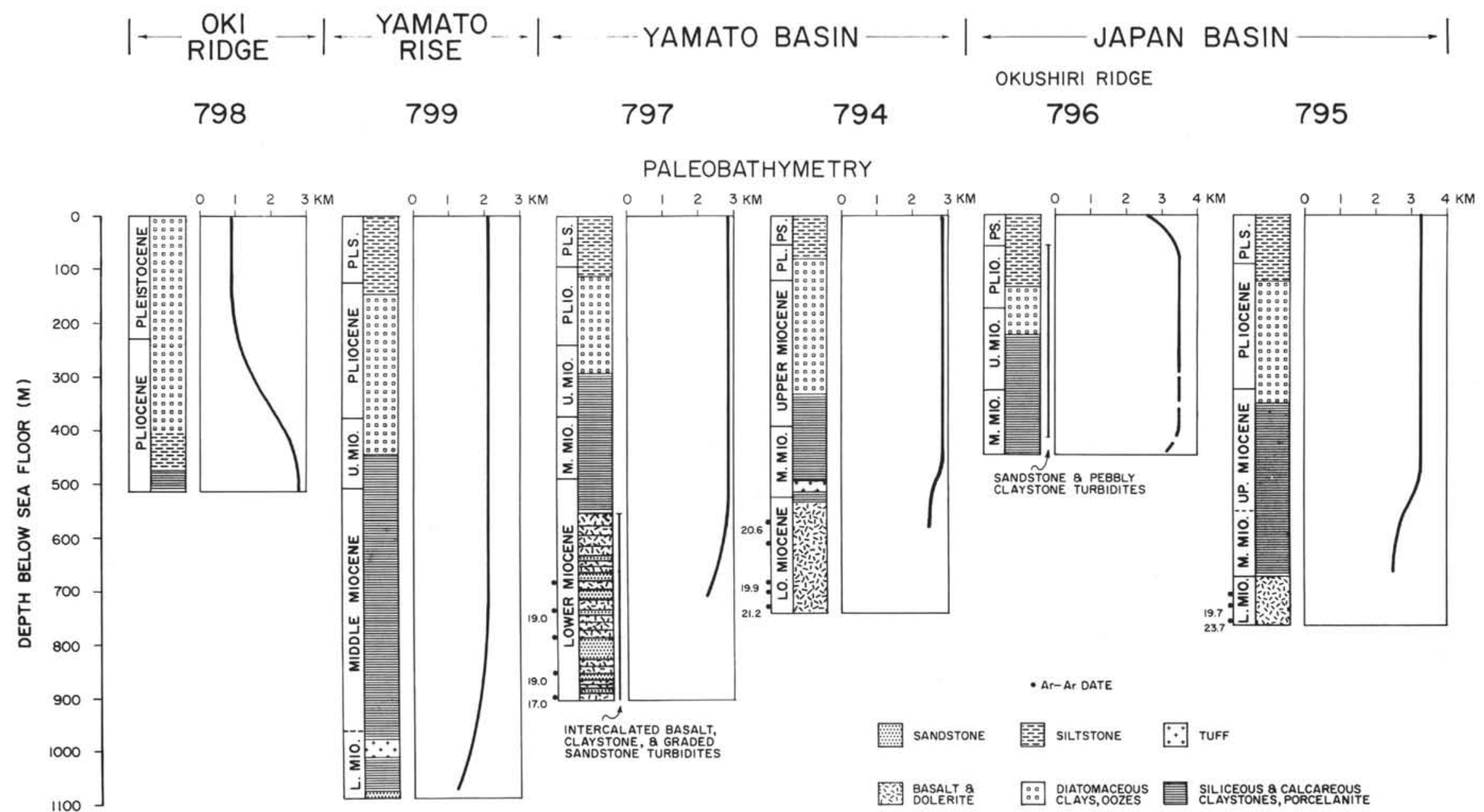

Figure 12. Paleobathymetric histories, ages, thicknesses, and generalized lithofacies for ODP Sites 794, 795, 796, 797, 798, and 799 in the Japan Sea. Age assignments are based on biostratigraphic, magnetostratigraphic, and radiometric ages and data in Tamaki, Pisciotto, Allen, et al. (1990), Ingle, Suyehiro, von Breymann, et al. (1990), and updated analyses reported in this volume by Alexandrovich, Brunner, Burckle, Kaneoka, Kato, Koizumi, Krumsiek, Ling, Muza, and Rahman. Paleobathymetric curves are based upon interpretation of benthic foraminiferal biofacies reported from these sites by Brunner (this volume), Kato (this volume), and Nomura (this volume). See Figure 1 for locations. 

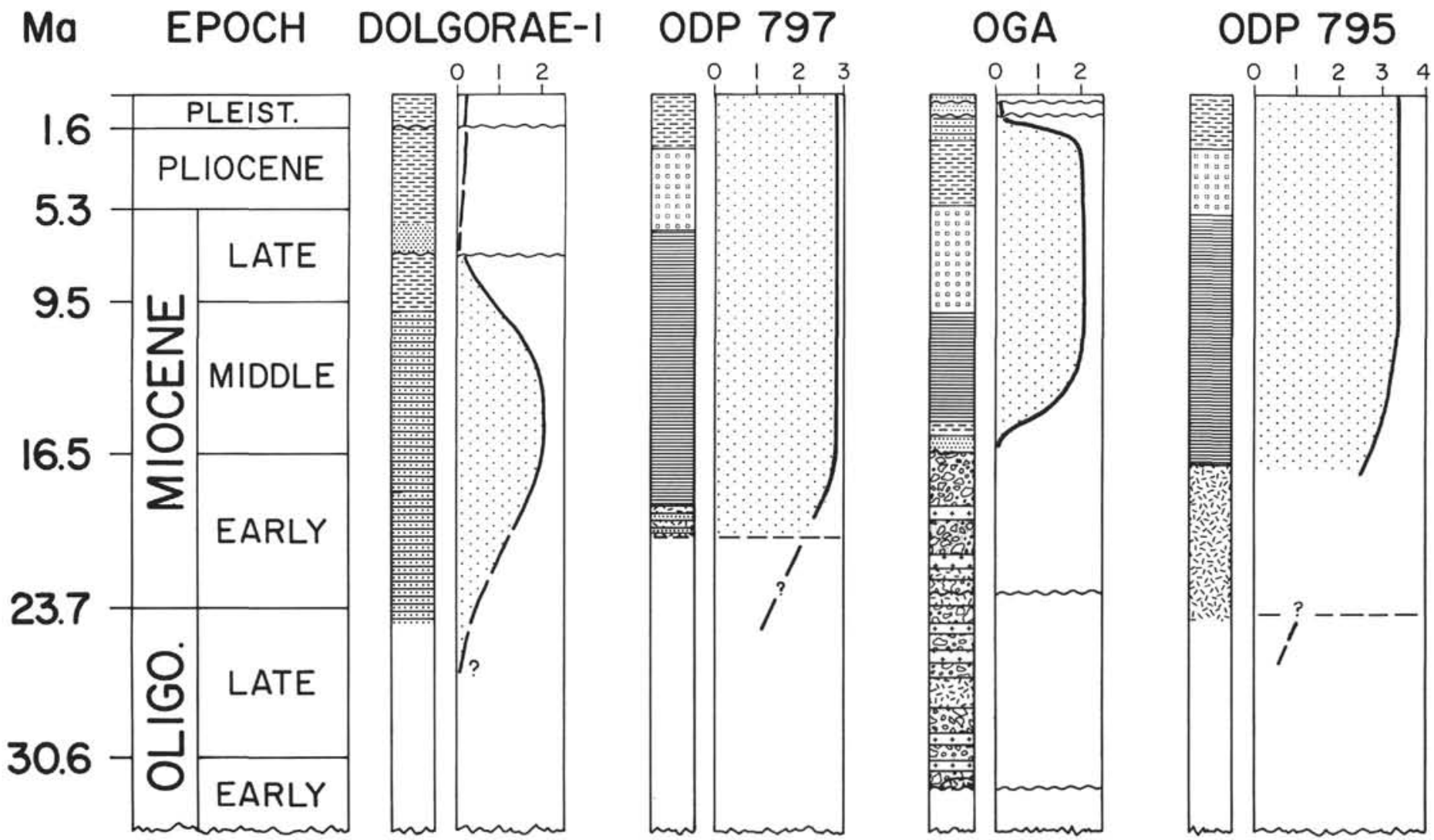

S. SAKHALIN

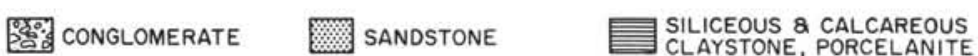

罣 SILTSTONE

$\because \because$ TUFF

WATER DEPTH

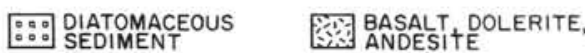

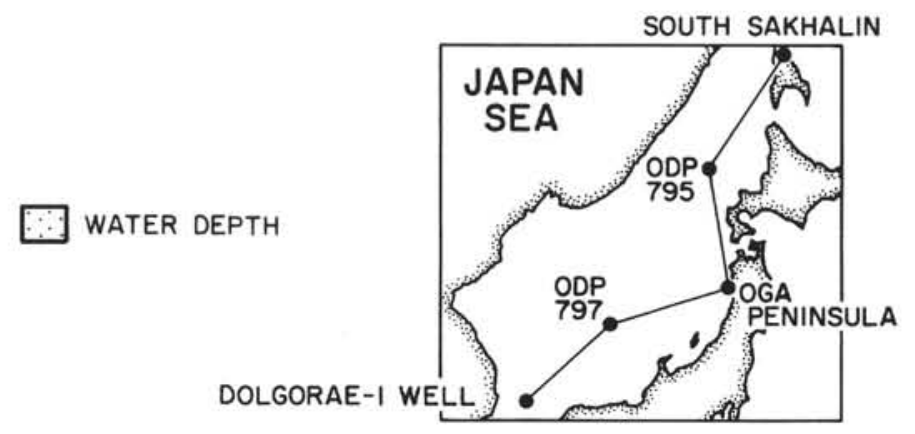

Figure 13. Paleobathymetric histories and lithofacies variations for five key Neogene sequences in the Japan Sea region plotted in terms of age/time including the Dolgorae-1 Well sequence representing the Tsushima Basin, ODP Site 797 representing the northern Yamato Basin, the Oga Peninsula surface section representing the inner arc area of western Honshu, ODP Site 795 representing the northern Japan Basin, and the southern Sakhalin surface section representing the northern margin of the Japan Sea. See Figures 4, 7, 9, 11, 12 and text for details of these sections and data sources. Ages, lithologies, and paleobathymetric history of the Dolgorae-1 Well slightly modified from Chough and Barg (1987); middle and lower Miocene lithologies are depicted as alternating sands and mudstones following these authors. 
Because of the uncertainty of the date of initial subsidence, an alternate initial curve is illustrated for Site 794 (Fig. 14) with an origin at $32 \mathrm{Ma}$, which is considered the oldest possible date for this event based on the age of basal Monzen rocks exposed in the adjacent Oga Peninsula section $125 \mathrm{~km}$ to the southwest of Site 794 (Figs. 1, 4, and 13). Tamaki et al. (this volume) cite evidence that suggests initial spreading in the eastern Japan Basin occurred as early as 30 or $28 \mathrm{Ma}$, an event which presumably would have directly influenced initial subsidence in the adjacent Site 794 area (Figs. 1 and 2).

The curve of initial subsidence for Site 794 tied to sea level at 23 Ma yields a tectonic or residual rate of subsidence of $725 \mathrm{~m} / \mathrm{m}$.y. for the period 23-19 Ma (Fig. 14). Alternatively, setting the initial age of subsidence at $32 \mathrm{Ma}$ yields a rate of ca. $223 \mathrm{~m} / \mathrm{m}$.y for this same period. Thus, either extreme yields an estimated rate of tectonic subsidence which exceeds that expected for simple thermal decay but is indicative of combined fault-assisted mechanical subsidence and rapid thermal cooling. Between 19 and 14 Ma tectonic subsidence slows dramatically to $60 \mathrm{~m} / \mathrm{m}$.y. at this site and subsequently remains at ca. $7-10 \mathrm{~m} / \mathrm{m}$.y. from $14 \mathrm{Ma}$ to the present, a rate that probably expresses remnant thermal decay (Fig. 14).

\section{GENERAL PATTERNS OF SUBSIDENCE}

The five subsidence histories derived for ODP Site 794, the Oga Peninsula, Pohang, and Sakhalin surface sections, and the Dolgorae-1 offshore well (Figs. 6, 8, 10,11 and 14) allow patterns of subsidence and uplift to be compared in an array of crustal and tectonic settings associated with the opening of the Japan Sea.

For example, extremes in sediment loading are represented by subsidence histories for the Dolgorae- 1 sequence in the southern Tsushima Basin where accumulation of about $10,000 \mathrm{~m}$ of Neogene sediment induced major isostatic effects. In comparison, the relatively thin $(543 \mathrm{~m})$ column of Neogene sediment at ODP Site 794 in the northern Yamato Basin has induced only minimal isostatic response over the past $18 \mathrm{~m} . \mathrm{y}$. following the rapid tectonic production of this deep basin (Figs. 11 and 14).

Subsidence profiles at each of the locations analyzed presumably also reflect events peculiar to their individual tectonic and crustal settings. Subsidence of the southern Sakhalin area was influenced by the pre-existing crustal fabric of the Japan and Kurile Islands, the evolution of the Japan and Kurile Basins, adjustments of the Amurian and Okhotsk microplates, as well as motion along the zone of major strike-slip faulting proposed in this area by Jolivet and Huchon (1989) and Jolivet et al. (1991). Subsidence of the Pohang section and Dolgorae-1 sequence in the southern Japan Sea occurred in an area of extended continental crust that has been directly influenced by motion of the Philippine plate, opening of the Shikoku basin, and Neogene strike-slip motion between the continental blocks of the Korean Peninsula to the east and the rotating Japan Arc to the southeast (Kanaori, 1990). Subsidence in the Oga Peninsula area occurred on rifted continental crust and was influenced by Neogene events in the adjacent northern Japan Arc, spreading and subsidence in the adjacent Japan and Yamato basins, and by Pliocene-Pleistocene translation and compression associated with the evolving EurasiaAmerican plate boundary in this region (Tamaki and Honza, 1985; Kitamura et al., 1989; Tsuchiya, 1990). Finally, subsidence at ODP Site 794 in the northern Yamato Basin presumably reflects rapid extension of continental crust as well as coincident production and cooling of oceanic crust in the immediately adjacent Japan Basin (Tamaki et al., this volume).

Despite these major differences in depositional, tectonic and crustal settings, the five Neogene columns analyzed (1) exhibit basic similarity in their overall patterns of subsidence and uplift, (2) collectively define the timing and rates of subsidence characterizing the early and mature stages in the formation of the Japan Sea, and (3) illustrate the progressive onset of compressional tectonics that con-

\section{ODP 794}

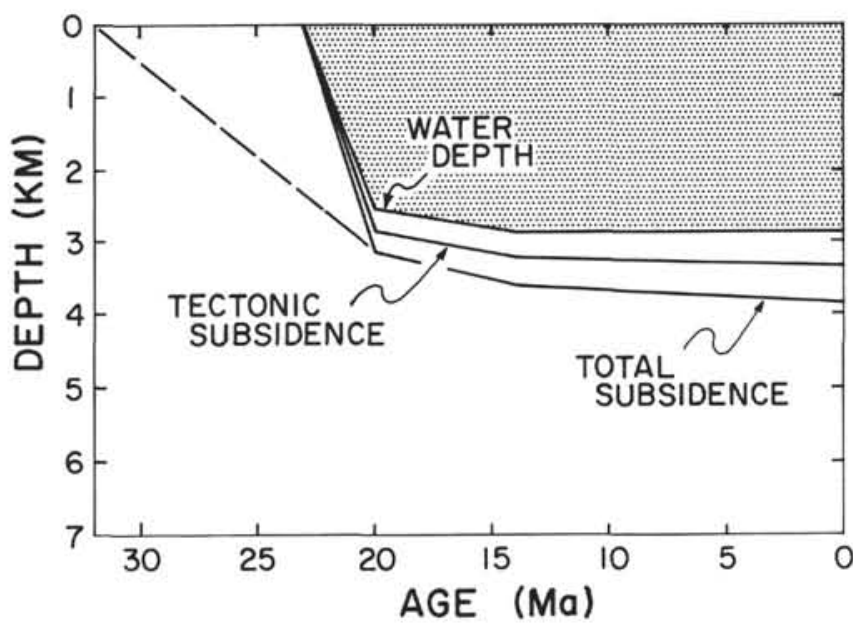

Figure 14. Backstripped subsidence plot for the stratigraphic column penetrated at ODP Site 794 in the Yamato Basin illustrating paleobathymetry and tectonic (residual) and total subsidence assuming local Airy isostasy. A dashed line illustrates the pattern of subsidence assuming the oldest possible age of $32 \mathrm{Ma}$ for initiation of this event based on radiometric dates within the basal portions of the Monzen Formation exposed on adjacent Honshu Island (see Fig. 4). The solid curve of initial subsidence has its origin at $23 \mathrm{Ma}$, the youngest possible date for this event based on radiometric dates in the Daijima Formation exposed on adjacent Honshu and the fact that Kaneoka (this volume) reports radiometric dates of 19.9-21.2 Ma from basalts interbedded with bathyal marine sediments in the lower portion of the section penetrated at ODP Site 794.

tinue to deform the backarc region likely marking the initial phase in the destruction of the sea. Dissimilarities between individual subsidence histories largely express contrasting sediment loads and crustal settings that in turn affected timing and rate of rift propagation (Figs. 15,16 , and 17).

\section{Rates of Subsidence and Uplift}

Short term rates of subsidence and uplift calculated from the average slopes of individual segments of all five tectonic subsidence curves illustrate that variations in rates over time define (1) the pace and bimodal form of subsidence and basin formation between $30 \mathrm{Ma}$ and $10 \mathrm{Ma}$ and (2) the increasing pace of compressive uplift and subsidence deforming the backarc area from $10 \mathrm{Ma}$ to the present (Fig. 15). Although the average rate of tectonic subsidence during the late Oligocene-late Miocene (32-10 Ma) extensional phase of basin development was ca. 200-300 m/m.y., maximum rates of subsidence exceeded $900 \mathrm{~m} / \mathrm{m}$.y. during the two episodes of rapid subsidence from 23-19 Ma and 16-12.5 Ma. Rates of subsidence clearly decrease to a minimum ca. $10 \mathrm{Ma}$ as extension waned and after which compression and uplift prevail (Fig. 15). Maximum rates of compressional uplift exceeding $1000 \mathrm{~m} / \mathrm{m}$.y. occur during Pleistocene time with simultaneous tectonically driven subsidence occurring at rates of $100-400 \mathrm{~m} / \mathrm{m}$.y. as a function of the convergent neotectonic deformation along the northeastern margin of the Japan Sea.

\section{Total Subsidence}

Slopes of both total and tectonic (residual) curves of subsidence for the five sections analyzed were summed for each $2.5 \mathrm{~m}$.y. interval to obtain average curves reflecting general patterns of subsidence and uplift during the evolution of the Japan Sea (Figs. 16 and 17). 


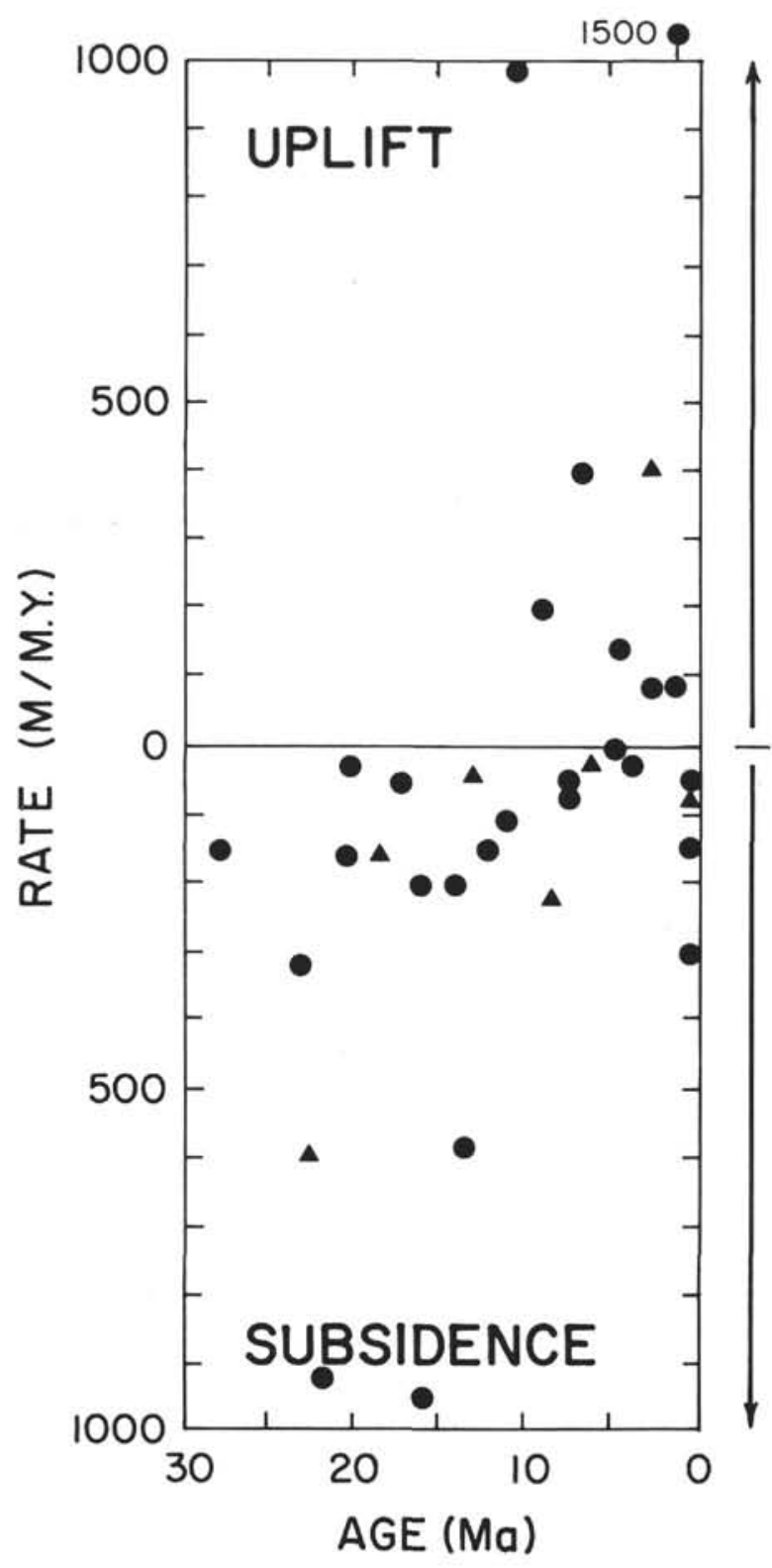

Figure 15. Variations in rates of late Oligocene through Recent tectonic (residual) subsidence and uplift in the Japan Sea region as calculated from variations in the slopes and signs of backstripped subsidence curves. Solid dots represent rates derived from subsidence curves constructed for the Oga Peninsula and Pohang onshore sections, the offshore Dolgorae-1 Well, and ODP Site 794. Solid triangles represent rates derived from the subsidence curve constructed for the southern Sakhalin onshore section. Note that subsidence dominates the period between 32 and 10 Ma presumably expressing an extensional tectonic regime with maximum rates of subsidence occurring between 23 and $15 \mathrm{Ma}$ (early and middle Miocene). Initial evidence of uplift occurs ca. $10 \mathrm{Ma}$ with maximum rates of uplift appearing during Pliocene-Pleistocene time along with coincident subsidence occurring as a function of accelerating compressional deformation in the eastern Japan Sea.

Individual total subsidence curves together with the average curve demonstrate that all five locations experienced a similar pattern of subsidence resulting from the combined effects of isostatic adjustments to load and tectonically driven subsidence, although the range of values expressing these events is large (Fig. 16). The envelope of maximum and minimum limits of vertical motion defined by the

\section{TOTAL SUBSIDENCE}

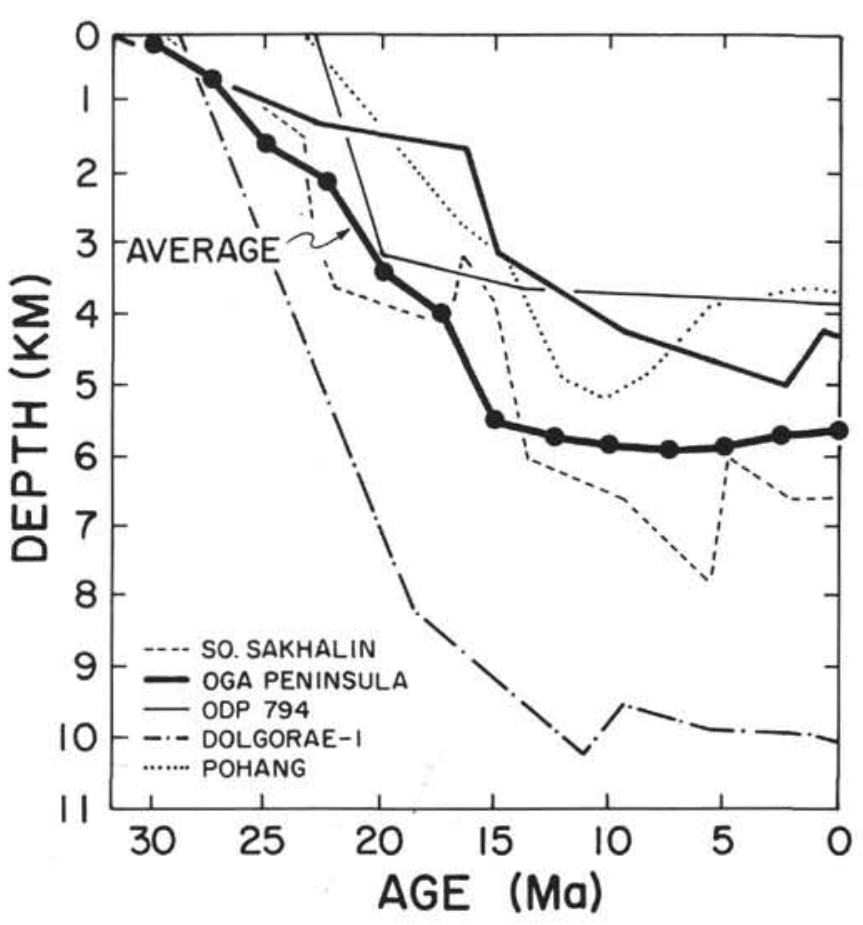

Figure 16. Average total subsidence curve for five Neogene sequences within the Japan Sea region including the Oga Peninsula section representing the northwestern Honshu area, the Pohang section and Dolgorae-1 Well representing the Tsushima Basin and the southern margin of the Japan Sea, ODP Site 794 representing events at the juncture between the Yamato and Japan basins, and the southern Sakhalin section representing the northern margin of the Japan Sea (see Fig. 1 for locations). Slopes of the five individual subsidence curves were averaged for each $2.5 \mathrm{~m}$.y. interval to obtain the average curve of total subsidence/uplift. Note that the average curve incorporates the effects of both maximum and minimum rates of sediment loading within the Japan Sea as represented by the Dolgorae-1 Well and ODP Site 794, respectively (see Figs. 11 and 14).

individual curves expresses the range of variation induced by different rates of sediment accumulation, crustal setting, fault activation, etc., at each location.

Although the total subsidence curves for the Pohang section and ODP Site 794 sequences have their origins at $23 \mathrm{Ma}$, both of these areas may in fact have experienced initial subsidence ca. 32-30 Ma as noted earlier (Figs. 8 and 14). Thus, geologic evidence permits an assumption of coincident initial subsidence ca. $30 \mathrm{Ma}$ for all five sites (Fig. 16) which, if imposed, would further emphasize the similarity of total subsidence patterns at these locations.

The average curve of total subsidence yields a rate of $323 \mathrm{~m} / \mathrm{m}$.y. for late Oligocene-middle Miocene time (32-15 Ma), the period encompassing the formation of both the deep basins and marginal sub-basins of the Japan Sea (Fig. 16). In contrast, the youngest segment of this latter curve indicates the effects of regional uplift just slightly exceeded the effects of local sediment loading from latest Miocene time to the present.

\section{Tectonic Subsidence}

The average and individual curves of tectonic (residual) subsidence also illustrate that all five locations analyzed exhibit similar patterns of tectonically induced vertical motion despite their disparate local tectonic and crustal settings (Fig. 17). As might be expected, variability among this family of curves is relatively small compared 


\section{TECTONIC SUBSIDENCE / UPLIFT}

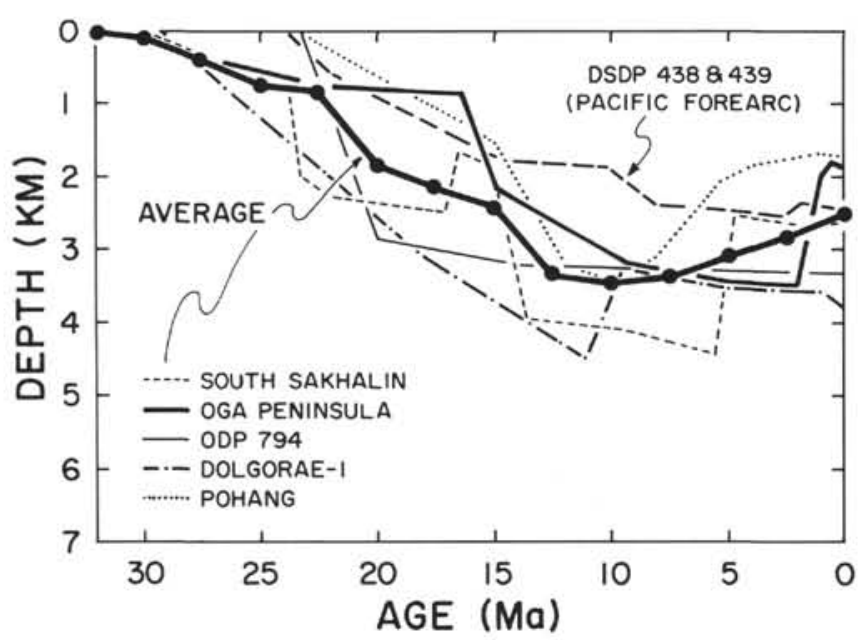

Figure 17. Average tectonic (residual) subsidence curve for five Neogene sequences within the Japan Sea region including the Oga Peninsula section representing the inner arc area of northwestern Honshu, the Pohang section and Dolgorae-1 Well representing the southern Tsushima Basin and the southern margin of the Japan Sea, ODP Site 794 representing the juncture between the Yamato and Japan basins, and the southern Sakhalin section representing the northern margin of the Japan Sea (see Fig. 1 for locations). Slopes of the five individual subsidence curves were averaged for each 2.5 m.y. interval to obtain the average curve of tectonic subsidence/uplift. Note that a bold dashed line illustrates Neogene subsidence in the Ishikari-Hidaka forearc basin off northeastern Honshu as determined by von Huene and Arthur (1982); this curve is not included in the average curve of subsidence. Although rates differ, both the backarc and forearc areas apparently experienced similar patterns of subsidence during Miocene time.

with the range of variation inherent to patterns of total subsidence. Nevertheless, significant differences are apparent in the timing of abrupt subsidence events likely reflecting differences in activation of local rift systems and local differences in thermal decay due to variations in thickness of the overlying sediment blanket, rates of crustal extension/thinning, etc. The average curve yields an initial rate of tectonic subsidence of ca. $100 \mathrm{~m} / \mathrm{m}$.y. during late Oligocene time-early Miocene time (32-23 Ma) supporting the idea that incipient crustal extension and thermal decay were responsible for this juvenile phase of backarc evolution.

A sharp increase in the average rate of tectonic subsidence to ca. $300 \mathrm{~m} / \mathrm{m}$.y. occurs between 23 and $19 \mathrm{Ma}$ (Fig. 17) and highlights the rapid subsidence presumably associated with formation of the Japan Basin by seafloor spreading and the Yamato and Tsushima basins via extension of continental crust (Hamano et al., 1989; Tamaki et al., this volume). The rapid episode of early Miocene subsidence recorded in the southern Sakhalin section may also express effects induced by coincident production of ocean crust and subsidence of the adjacent Kurile basin which likely underwent rapid spreading in concert with spreading in the Japan Basin. Moreover, initial subsidence in the Pacific forearc region off northwestern Honshu also occurred ca. 24 $\mathrm{Ma}$ as illustrated by a subsidence curve for DSDP Sites 438-439 presented by von Huene and Arthur (1982) and plotted on Figure 17.

A second episode of rapid subsidence in middle Miocene time 15-13 $\mathrm{Ma}$ is indicated by the average tectonic curve; individual curves indicate this event began ca. $16 \mathrm{Ma}$ and ceased ca. $12.5 \mathrm{Ma}$ (Fig. 17). The highest rates of tectonic subsidence are recorded during this period (Fig. 13), which is coincident with the period of rapid are rotation and extension implied by paleomagnetic evidence assembled by Otofuji and Matsuda (1983, 1987), Otofuji et al. (1985), Hirooka et al. (1990), and Otofuji et al. (1991). The steep middle Miocene segment of the average tectonic curve largely reflects the period of rapid subsidence responsible for formation of the array of smaller sub-basins around the perimeter of the Japan Sea in turn implying rapid propagation of rifts into the arc regions and other marginal areas of previously weakened continental crust (Fig. 17). The subsequent reduction in slope of the average curve indicates a period of relatively slow thermal subsidence $(<100$ $\mathrm{m} / \mathrm{m} . \mathrm{y}$.) dominated the final phase of Miocene basin evolution between 12.5 and $10 \mathrm{Ma}$.

Late Miocene compressional deformation begins in the southern Japan Sea between 11 and $6 \mathrm{Ma}$ (Pohang and Dologorae-1 sequences) and is manifested by the initial indications of uplift on the average tectonic curve (Fig. 17). Acceleration of uplift and deformation in the northeast Japan and the Kurile Arcs commenced ca. $5 \mathrm{Ma}$ (Fig. 17) as evidenced by uplift of Miocene basins in the Ou Backbone Range area of Honshu, as well as in Hokkaido, and the southern Sakhalin area. Pronounced compressional uplift and deformation of the Okushiri Ridge, Oki Ridge and Islands, Sado Island, and the complex of sub-basins arrayed along the eastern margin of the Japan Sea began in the late Pliocene and increased during middle and late Pleistocene time (Fig. 17). Shallow seismic activity, active thrust faulting, multiple Pleistocene unconformities, and deformed Pleistocene-Holocene terraces indicate convergent neotectonic processes are continuing to deform this region (Ota, 1973; Ota et el., 1976; Tamaki and Honza, 1985: Jolivet and Houchon, 1989). Tamaki and Honza (1985) and Jolivet and Huchon (1989) view this eastern zone of en echelon ridge and basin deformation as the site of unusually dynamic convergent, compressional, and translational processes likely associated with the birth of a new Eurasia-American plate boundary in this area.

\section{Forearc Subsidence}

von Huene and Arthur (1982) and von Huene et al. (1982) summarize the Neogene subsidence history for the forearc region off northeastern Honshu as deduced from stratigraphic and foraminiferal data obtained via drilling at DSDP Sites 438 and 439 (Figs. 1 and 18). This latter curve has been plotted together with the tectonic subsidence curves for the Japan Sea so to compare forearc and backarc patterns of Neogene subsidence (Fig. 17). Interestingly, the initiation of subsidence in the Ishikari-Hidaka forearc basin began ca. $24 \mathrm{Ma}$ as noted earlier, a date essentially coincident with the period of formation of the major backarc basins of the Japan Sea demonstrating subsidence of the entire Northeast Japan Arc region during this process. The subsidence curve for DSDP Sites $438-439$ also illustrates that the trajectory of subsequent forearc subsidence parallels the general pattern of backarc subsidence throughout the remainder of Miocene time until interrupted by abrupt uplift ca. 3 Ma (Keller, 1980) coincident with accelerating uplift, deformation, and volcanism recorded on Honshu and in the eastern Japan Sea (Fig. 18).

\section{SUMMARY AND CONCLUSIONS}

Prior to ODP drilling it was not clear when the deep basins of the Japan Sea had subsided to their present depths nor when the sea had assumed its basic configuration. Most of the pre-ODP offshore evidence including heat flow data, extrapolated rates of sediment accumulation, seismic evidence of basement depths, magnetic anomaly patterns, and radiometric dating of dredged volcanic rocks pointed to formation of the Japan Sea in late Oligocene-early Miocene time (Tamaki, 1986, 1988; Kimura and Tamaki, 1986; Tamaki and Kobayashi, 1988). In contrast, parallel studies of onshore Neogene sequences repeatedly demonstrated that initial marine deposition in the many sub-basins formed along the eastern margin of the sea had occurred in early middle Miocene time ca. 16-15 Ma. This latter event, together with abundant paleomagnetic data implying middle Miocene clockwise rotation of southwest Japan, were commonly cited as key evidence that major extension and subsidence of the Japan 


\section{DSDP $438 \& 439$}

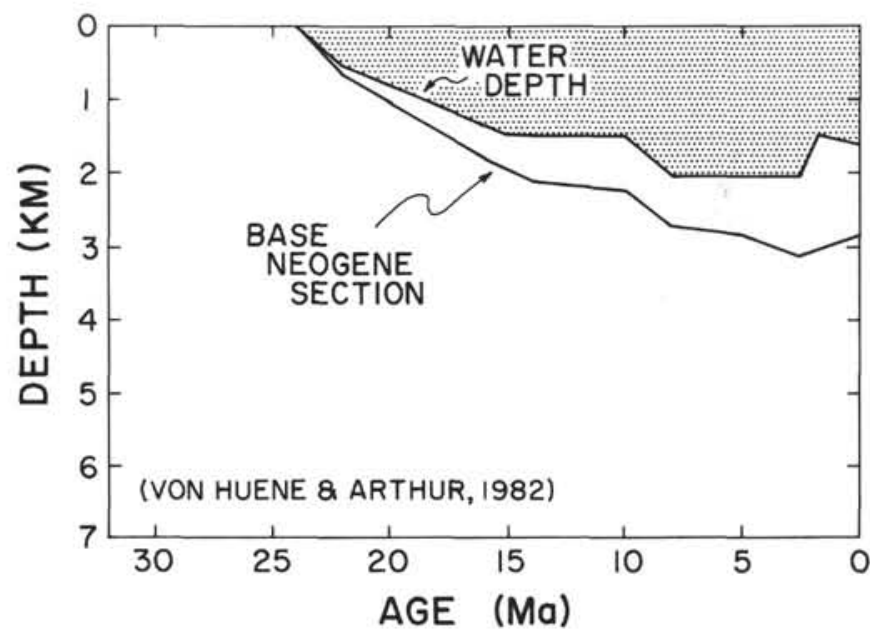

Figure 18. Subsidence and paleobathymetric history for the composite Neogene sequence penetrated at DSDP Sites 438 and 439 in the Ishikari-Hidaka forearc basin off northeastern Honshu, Japan as reported by von Huene and Arthur (1982). See Figure 1 for location.

Sea had most likely occurred ca. $15 \mathrm{Ma}$. The successful completion of ODP drilling in the Japan Sea and penetration of the Neogene sediment blanket and underlying volcanic rocks in the deep basins of the Japan Sea has provided the missing data to resolve aspects of these conflicts, correlate onshore and offshore Neogene records, and reconstruct a comprehensive history of the Japan Sea.

Paleobathymetric evidence and radiometric and biostratigraphic ages established at the base of the Neogene sediment columns at ODP Sites 794, 795, and 797 have now firmly established that the major Yamato and Japan basins of the Japan Sea had in fact subsided to near their present water depths by $20-18 \mathrm{Ma}$. Subsidence analysis of the Dolgorae-1 offshore well in the southern Japan Sea (Chough and Barg, 1987) indicates that the Tsushima basin had also subsided to a depth of ca. $2 \mathrm{~km}$ by 19-18 Ma. Thus, all three of the major deep basins of the Japan Sea were in place and with their basin plains at minimum depths of 2 to $3 \mathrm{~km}$ by $20-18 \mathrm{Ma}$.

This study utilized backstripped subsidence analyses of five Neogene onshore and offshore sequences to define basic patterns of subsidence and uplift characterizing the evolution of the Japan Sea over the past 32 m.y. Data on variations in stratigraphic thickness, lithology, age, and paleobathymetry in each of the five columns were used to calculate (1) curves of total subsidence representing the cumulative loading effects of sediment accumulation and variations in water depth over time together with any tectonically induced subsidence or uplift and (2) curves of tectonic subsidence representing any residual component of vertical motion remaining after loading effects were removed. The five stratigraphic sections utilized include (1) the Pohang section in southeastern Korea deposited on extended continental crust, (2) the Dolgorae-1 offshore well representing a highly sedimented location in the southern Tsushima Basin previously analyzed by Chough and Barg (1987), (3) the Oga Peninsula section of northeastern Honshu representing deposition, subsidence, and uplift in a typical Miocene sub-basin in an inner arc area of rifted continental crust, (4) ODP Site 794 at the juncture between the deep Yamato and Japan basins reflecting subsidence of both extended continental crust and adjacent production of oceanic crust, and (5) the southern Sakhalin section representing subsidence along the northern margin of the Japan Sea adjacent to the Kurile Basin. Subsidence histories for all five sections display generally similar patterns of subsidence and uplift with specific differences in the timing and rates of subsidence between sites largely a function of contrasting sediment loads and variation in the age of rifting in areas of unextended vs. thinned/extended continental crust-differences clearly expressed by the envelope of maximum and minimum rates of vertical motion delimited at the five locations analyzed (Fig. 19).

Average curves of total and tectonic subsidence for the backarc area were constructed by summing values for all five sections for each $2.5 \mathrm{~m} . \mathrm{y}$. interval between $32 \mathrm{Ma}$ and $0 \mathrm{Ma}$ as presented on Figure 19. A comparative curve illustrating simple lithospheric cooling (e.g., Parsons and Sclater, 1977) allows recognition of those periods when the average rate of backarc subsidence significantly exceeded predicted thermal decay (Fig. 19).

The overall pattern of subsidence and uplift illustrated by the averaged curves indicates that between 32 and $10 \mathrm{Ma}$ initial extension and subsequent subsidence of the Japan Sea occurred in four step-like phases involving alternating dominance of thermal and mechanical subsidence. Regional uplift ca. 11-10 Ma terminates the latter extensional phase of backarc evolution ca. 11-10 Ma and signaled the onset of compressional tectonics that have dominated the evolution of the Japan Sea region to the present. Analysis of stratigraphic, geochronologic, and paleobathymetric data from onshore sections, offshore wells, and ODP sites together with the results of quantitative subsidence analysis of five selected Neogene sequences in the Japan Sea backarc region lead to the following observations and conclusions.

1. The collective stratigraphic and radiometric age data from onshore sequences around the rim of the Japan Sea indicate backarc extension, crustal thinning, and initial subsidence began ca. 32-30 Ma in Oligocene time accompanied by widespread deposition of non-marine syn-rift deposits broadly correlative with the Monzen Formation of northern Honshu and informally included in the "lower Green Tuff facies" by many workers. Interpretations of magnetic anomaly patterns in the northeastern Japan Basin indicate that earliest seafloor spreading may have occurred in this area ca. 28-26 Ma (Tamaki and Kobayashi, 1988; Tamaki et al., this volume).

2. The average curve of tectonic subsidence (Fig. 19) indicates that the regional pattern of initial rifting and subsidence expressed in both onshore and offshore sections was underway between $32 \mathrm{Ma}$ and $23 \mathrm{Ma}$ at rates compatible with simple thermal decay (Fig. 19). Individual areas undergoing rapid crustal extension and/or spreading such as the northern Yamato Basin (Site 794) were effected by rates of initial subsidence exceeding those expected for thermal decay implying dominance of mechanical subsidence (200-300 m/m.y.); similar rates of subsidence likely accompanied initial spreading in the eastern Japan Basin ca. 28-26 Ma.

3. The first regional episode of accelerated backarc subsidence occurred during the early Miocene between 24-23 Ma and $19 \mathrm{Ma}$ (Fig. 19) when maximum rates of subsidence in individual sub-basins exceeded $900 \mathrm{~m} / \mathrm{m} . \mathrm{y}$. The relatively short duration and high rates of subsidence marking this period are indicative of the predicted pattern for initial subsidence of pull-apart basins (Pitman and Andrews, 1985). This observation supports the concept of a general pull-apart origin for the Japan Sea proposed by Lallemand and Jolivet (1985), Kimura and Tamaki (1988), Tamaki (1988), and Jolivet et al. (1989). Early Miocene rapid subsidence is also consistent with the effects of strike-slip motion on major boundary faults accommodating backarc spreading during this period (Jolivet and Tamaki, this volume) as well as coincident rapid rift propagation (Tamaki et el., this volume).

4. The early Miocene period of rapid backarc subsidence was accompanied by (a) arc rotation and/or drift (Hayashida et al., 1991), (b) a massive episode of lower Miocene basaltic magmatism (Fujioka, 1989), (c) the initial appearance of bathyal marine deposits in marginal sub-basins (e.g., Kim, 1990; Sato et al., 1991), (d) deposition at ODP Sites 794 and 797 of lower Miocene sediment in the Yamato Basin at middle to lower bathyal depths, and (e) early Miocene production of basaltic backarc crust and seafloor (23.7-17.1 Ma) in the Japan and Yamato basins as sampled at ODP Sites 794, 795, and 


\section{JAPAN SEA}

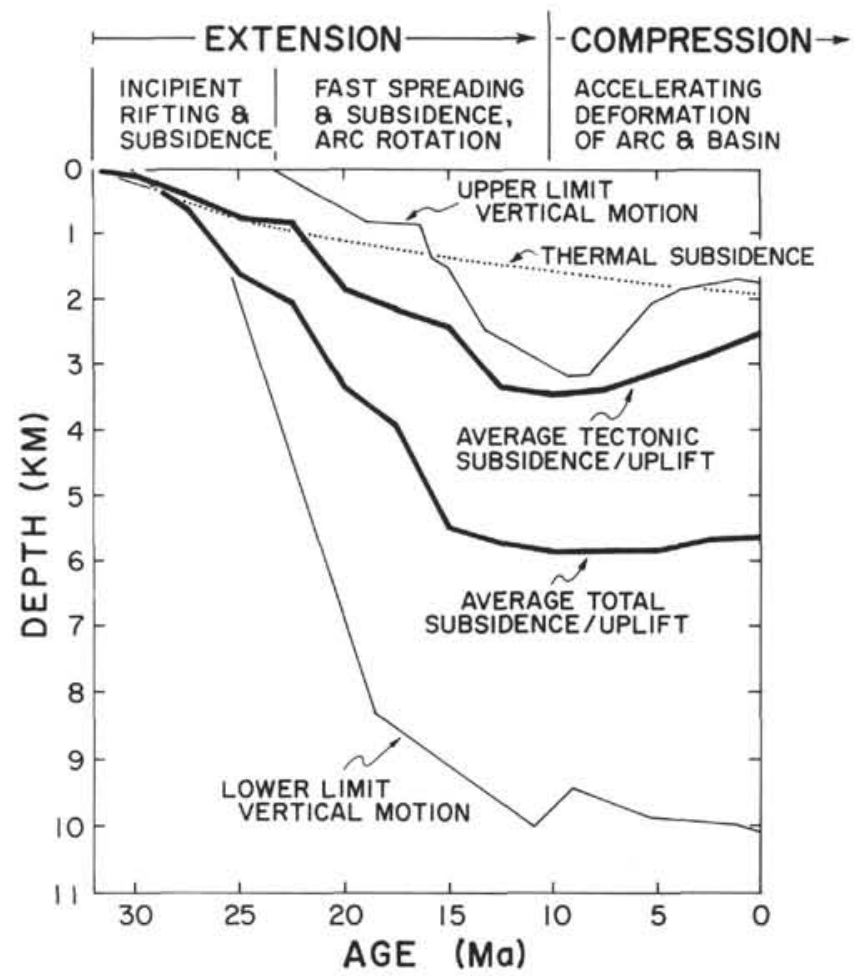

Figure 19. Summary of tectonic (residual) and total subsidence patterns in the Japan Sea backarc area as derived by backstripping analysis of five stratigraphic sequences including the Pohang section, Korea, the Oga Peninsula section, Japan, the southern Sakhalin (Makarov River) section, Russia, the Dolgorae-1 offshore well in the Tsushima Basin, and ODP Site 794 at the juncture of the Yamato and Japan basins. The envelope of maximum and minimum limits of vertical motion experienced by the five stratigraphic sequences is defined by the collective extremes of individual total and tectonic subsidence curves derived for the five sites analyzed. Curves of average total and tectonic subsidence were derived by averaging the slopes of individual curves for each $2.5 \mathrm{~m} . \mathrm{y}$. interval analyzed. The thermal subsidence curve expresses the relationship between simple lithospheric cooling and the square root of time presented by Parsons and Sclater (1977) with the onset of cooling set at $30 \mathrm{Ma}$. Note that early backarc rifting and subsidence follow the trajectory for thermal subsidence between 32 and $23 \mathrm{Ma}$. Subsequent rates of subsidence between 23 and $13 \mathrm{Ma}$ exceed normal thermal decay in turn implying a significant component of mechanically controlled subsidence with clear dominance of mechanical effects during episodes of unusually rapid subsidence between 23 and $19 \mathrm{Ma}$ and 15 and $12.5 \mathrm{Ma}$. Initial evidence of uplift occurs ca. $10 \mathrm{Ma}$ and is assumed to mark the termination of the extensional regime governing formation of the Japan Sea and the initiation of compressive deformation of the arc and backarc area with uplift and compression accelerating ca. $5 \mathrm{Ma}$.

797. The temporal convergence of these events and processes point to this period as the time of principle formation of the major backarc basins in the Japan Sea. Initial subsidence in the Pacific forearc region off northwest Honshu also commenced ca. $24 \mathrm{Ma}$ with subsequent subsidence following the trajectory of concurrent subsidence in the backarc region.

5. The average rate of tectonic subsidence slowed during the late early Miocene to early middle Miocene (19-15 Ma) suggesting that thermal effects dominated this period of basin development. Alternatively, a concurrent episode of rapid uplift in southern Sakhalin suggests this area may have operated as a structural hinge during extension and subsidence in the central and southern Japan Sea.
6. A second episode of accelerated subsidence occurred in early middle Miocene time ca. 16-15 Ma reflecting the widespread formation of margin sub-basins as typified by the Oga-Akita and Niigata basins of northwestern Honshu (Fig. 19). Abundant paleomagnetic data imply that this phase of subsidence was accompanied by a rapid clockwise rotation of southwest Japan and further backarc extension (e.g., Otofuji et al., 1991). Many if not most of the middle Miocene sub-basins formed via the rapid propagation of rifts into areas of previously weakened continental crust accompanied by a second intense episode of basaltic magmatism (Tsuchiya, 1990). Rates of tectonic subsidence exceeded $900 \mathrm{~m} / \mathrm{m}$.y. within individual basins during this period suggesting pull-apart origins for many of these rifts consistent with the high angle normal faults commonly bounding individual sub-basins and evidence of sediment starvation. Metalliferous hydrothermal deposition occurred at the climax of middle Miocene sub-basin formation typified by the Kuroko massive sulfide ores of northern Honshu (Ohmoto and Skinner, 1983).

7. Slow thermal subsidence characterized the mature and tectonically quiescent phase of backarc evolution from 12.5 to $10 \mathrm{Ma}$ (Fig. 19).

8. Widespread uplift and deformation of Miocene basin-fill sequences initially occurred along the southern margin of the Japan Sea ca. 11-10 Ma, signaling a fundamental change from an extensional to a compressional tectonic regime in the backarc region. Rates of uplift increased in latest Miocene time ca. $5 \mathrm{Ma}$ accompanied by deformation of Miocene basins within the volcanic arc and inner arc areas of northern Honshu, Hokkaido, and Sakhalin.

9. Rates of uplift accompanying Pliocene-Pleistocene compressive deformation along the eastern margin of the Japan Sea commonly exceeded $500 \mathrm{~m} / \mathrm{m}$.y. matching rates of uplift reported from other areas on Honshu (e.g., Niitsuma, 1978; Sugi et al., 1983). Multiple angular unconformities within individual Pleistocene slope, shelf, and terrace sequences emphasize the episodic nature of the deformational process. Seismic reflection profiles through the central and eastern areas of the Japan Sea (Tamaki, 1988) clearly depict evidence of a widespread middle Pleistocene episode of deformation that was responsible for the topographic reorganization of over half of the sea into its modern continental borderland-style configuration. Ongoing convergent, compressional, and translational tectonic processes are continuing to mold and deform the backarc region at an accelerating rate (Fig. 19) and likely herald an early stage in the destruction of the sea.

In summary, quantitative subsidence analysis of selected onshore and offshore Neogene sequences in the Japan Sea indicates that the evolution of the sea can be divided into eight phases based on major variations in rates and patterns of subsidence and uplift expressed in a variety of depositional, crustal, and tectonic settings. Extension and subsidence dominate the period from $32 \mathrm{Ma}$ to $10 \mathrm{Ma}$ whereas compressional uplift and deformation are the rule from $10 \mathrm{Ma}$ to the present. Discrete stages or phases in the subsidence/uplift history of the sea include; (1) relatively slow initial extension, crustal thinning, and thermal subsidence between 32 and $23 \mathrm{Ma}$ accompanied by widespread non-marine syn-rift deposition with possible initial spreading in the Japan Basin ca. 28 and $26 \mathrm{Ma}$, (2) rapid mechanical subsidence to bathyal depths and formation of the major backarc basins between 23 and 19 Ma via spreading and crustal extension accompanied by arc rotation/drift and intensive basaltic magmatism with the Japan, Yamato, and Tsushima basins arriving at or near their present water depths by 20 to $18 \mathrm{Ma}$, (3) slow thermal subsidence between 19 and $15 \mathrm{Ma}$, (4) a second episode of rapid subsidence between 15 and $12.5 \mathrm{Ma}$ with widespread formation of marginal sub-basins within the arc and around the margin of the sea in areas of previously weakened continental crust, (5) a return to slow thermally dominated subsidence between 12.5 and $10 \mathrm{Ma}$ and onset of compressional deformation in the southern Japan Sea from 10 to $7 \mathrm{Ma}$, (7) acceleration of uplift and deformation of Miocene basins in the arc and arc-flank areas ca. $5 \mathrm{Ma}$, and (8) widespread compressional 
deformation and topographic reorganization of the central, eastern, and southern areas of the Japan Sea accompanied by high rates of uplift ( $>500 \mathrm{~m} / \mathrm{m} . \mathrm{y}$.) between 2 and $0 \mathrm{Ma}$.

\section{ACKNOWLEDGMENTS}

I want to thank my many Japanese colleagues who have introduced me to the Neogene geology and micropaleontology of Japan, most especially Yokichi Takayanagi of the Institute of Geology and Paleontology at Tohoku University. My interpretations of Neogene basin history in the Japan Sea region have been greatly influenced by discussions with these individuals in the field, at sea, and at scientific meetings over the past quarter century. Similarly, I thank Yuri Gladenkov of the Geological Institute of the U.S.S.R. Academy of Sciences for discussions and papers relating to the Neogene stratigraphy of Sakhalin and adjacent areas. I also gained many insights from field expeditions to the Pohang Basin of Korea with Bong Kyun Kim and his colleagues at Seoul National University.

It is a special pleasure to acknowledge the individual contributions of the many shipboard and shorebased scientists participating in Legs 127 and 128 which provided the fundamental data and interpretations necessary for subsidence analysis of our ODP sequences. In particular, Kensaku Tamaki and Kiyoshi Suyehiro of the Ocean Research Institute of the University of Tokyo have been especially helpful and supportive of our entire Leg 127-Leg 128 endeavor both at sea and onshore.

John Barron, David Scholl, Yokichi Takayanagi, and Richard Boettcher made suggestions for revision and improvement of an early version of this report. Discussions with Norman Sleep of Stanford University enhanced my understanding of backarc subsidence. Finally, I want to offer thanks and appreciation to Patricia McCrory of the U.S. Geological Survey for her advice and assistance in computing the subsidence histories presented in this report.

\section{REFERENCES}

Akimoto, K., and Hasegawa, S., 1989. Bathymetric distribution of the Recent benthic foraminifers around Japan-as a contribution to a new paleobathymetric scale. In Kitamura, N., Otsuki, K., and Ohguchi, T. (Eds.), Cenozoic Geotectonics of Northeast Honshu Arc. Chishitsugaku Ronshu, 32:229-240.

Allen, P. A., and Allen, J. R., 1990. Basin Analysis: Oxford (Blackwell Sci. Publ.). Asano, K., Ingle, J. C., Jr., and Takayanagi, Y., 1969. Neogene planktonic foraminiferal sequence in northern Honshu. In Bronnimann, R. P., and Renz, H. (Eds.), Proc. 1st Int. Conf. Planktonic Microfossils: Leiden (E. J. Brill), 1:14-25.

Barron, J. A., 1986. Updated diatom biostratigraphy for the Monterey Formation of California. In Casey, R. R., and Barron, J. A. (Eds.), Siliceous Microfossil and Microplankton Studies of the Monterey Formation and Modern Analogs. Soc. Econ. Paleontol. Mineral., Pacific Sect., 45:105-119.

Barron, J. A., Keller, G., and Dunn, D. A., 1985. A multiple microfossil biochronology for the Miocene. In Kennett, J. P. (Ed.), The Miocene Ocean: Paleoceanography and Biogeography. Mem.-Geol. Soc. Am., 163:21-36.

Berger, W. H., 1979. Impact of deep-sea drilling on paleoceanography. In Talwani, M., Hay, W., and Ryan, W.F.B. (Eds.), Deep Drilling Results in the Atlantic Ocean: Continental Margins and Paleoenvironment. Am. Geophys. Union, Maurice Ewing Ser., 3:1-26.

Berggren, W. A., Kent, D. V., Flynn, J. J., and Van Couvering, J. A., 1985. Cenozoic geochronology. Geol. Soc. Am. Bull., 96:1407-1418.

Bong, P. Y., 1984. Palynology of the Neogene strata in the Pohang sedimentary basin [Ph.D. dissert.]. Seoul Natl. Univ., Korea.

Chang, K. H., 1977. Late Mesozoic stratigraphy, sedimentation, and tectonics of southern Korea. J. Geol. Soc. Korea, 13:76-90.

Chough, S. K., and Barg, E., 1987. Tectonic history of Ulleung basin margin, East Sea (Sea of Japan). Geology, 15:45-48.

Chough, S. K., Hwang, I. G., and Choe, M. Y., 1990. The Miocene Doumsan fan-delta, southwest Korea: a composite fan-delta system in back-arc margin. J. Sediment. Petrol., 60:445-455.

Dickinson, W. D., Armin, R. A., Beckvar, N., Goodlin, T.C., Janecke, S. U., Mark, R. A., Norris, R. D., Radel, G., and Wortman, A. A., 1987. Geohistory analysis of rates of sediment accumulation and subsidence for selected California basins. In Ingersoll, R. V., and Ernst, W. G. (Eds.), Cenozoic Basin Development of Coastal California: Englewood Cliffs (Prentice-Hall), 1-23.

Fujioka, K., 1986. Synthesis of Neogene explosive volcanism of the Tohoku Arc, deduced from marine tephra drilled around the Japan Trench region. In Kagami, H., Karig, D. E., Colbourn, W. C., et al., Init. Repts. DSDP, 87: Washington (U.S. Govt. Printing Office), 703-726.

Fukasawa, K., 1990. Taxonomic study of Neogene and Quaternary benthic foraminifera of the Oga Peninsula [M.S. thesis]. Institute of Mining Geology, Akita University, Japan.

Ganzawa, Y., 1983. "Green tuff" movement defined by fission track ages of igneous rocks, Part 2 -Futomiyama area of Toyama Prefecture, Central Japan. Chishitsugaku Zasshi, 89:271-286.

, 1987. Fission track ages of volcanic rocks from Cretaceous to Tertiary in the inner belt of northeast Japan - Okushiri Isand, Oga Peninsula, and Asahi Mountains. Chishitsugaku Zasshi, 93:387-401.

Garrison, R. E., Mack, L. G., and Lee, Y. G., 1979. Petrology, sedimentology, and diagenesis of Miocene diatomaceous mudstones in the Pohang area. J. Geol. Soc. Korea, 15:229-247.

Gladenkov, Y. B., 1980. Stratigraphy of marine Paleogene and Neogene of northeast Asia (Chukotka, Kamchatka, and Sakhalin). AAPG Bull., 64:1087-1093.

, 1984a. Neogene stratigraphy of northeast Asia (Kamchatka, Sakhalin). In Ikebe, N., and Tsuchi, R. (Eds.), Pacific Neogene Datum Planes: Tokyo (Univ. Tokyo Press), 235-243.

-1984b. Neogene horizons and zones of northeastern Asia and details of correlation and refining. Proc. 27th Int. Geol. Congr., 1:89-106.

, 1990. System of the Neogene region and divisions of Kamchatka and Sakhalin: horizons, zones, and beds. Palaeogeogr., Palaeoclimatol., Palaeoecol., 77:199-201.

Gladenkov, Y. B., and Shantser, M. Y., 1990. Neogene of Kamchatka: stratigraphy and correlation of geological events. In Tsuchi, R. (Ed.), Pacific Neogene Events: Tokyo (Univ. Tokyo Press), 173-182.

Guber, A. L., and Merrill, S., 1983. Paleobathymetric significance of foraminifera from the Hokuroku District. In Ohmoto, H., and Skinner, B. (Eds.), The Kuroku and Related Volcanogenic Massive Sulfide Deposits. Econ. Geol. Monogr., 5:55-70.

Hamano, Y., Utada, H., and Segawa, J., 1989. Electrical conductivity structure and origin of the Yamato Basin. Abstract Vol. Mtg. Soc. Geomagn. Earth, Planet., Space Sci., 3:8. (Abstract)

Haq, B. U., Hardenbol, J., and Vail, P. R., 1987. Chronology of fluctuating sea levels since the Triassic. Science, 235:1156-1167.

Hasegawa, S., 1979. Foraminifera of the Himi Group, Central Japan. Sci. Repts. Tohoku Univ., Ser. 2, 49:89-163.

Hasegawa, S., Akimoto, K., Kitazato, H., and Matoba, Y., 1989. Late Cenozoic bathymetric indices based on benthic foraminifers in Japan. In Kitamura, N., Otsuki, K., and Ohguchi, T. (Eds.), Cenozoic Geotectonics of the Northeast Honshu Arc. Chishitsugaku Ronshu, 3:241-253.

Hashimoto, M. (Ed.), 1991. Geology of Japan: Tokyo (Terra Sci. Publ.).

Hayashida, A., Fukui, T., and Torii, M., 1991. Paleomagnetism of the Early Miocene Kani Group in southwest Japan and its implications for the opening of the Japan Sea. Geophys. Res. Lett., 18:1095-1098.

Hayward, B. W., 1990. Use of foraminiferal data in analysis of Taranaki Basin, New Zealand. J. Foraminiferal. Res., 20:71-83.

Hirooka, K., Yamada, R., Yamashita, M., and Takeuchi, A., 1990. Paleomagnetic evidence of the rotation of central Japan and the paleoposition of Japan. Palaeogr., Palaeoclimatol., Palaeoecol., 77:345-354.

Honza, E., Tamaki, K., Yuasa, M., and Murakami, F., 1979. Geological Map of the Southern Japan Sea and Tsushima Strait. Geol. Surv. Jpn. (scale 1:1,000,000).

Hoshi, K., 1988. Miocene ocean floor metamorphism during back-arc spreading in the Japan Sea [M.S. thesis]. Stanford Univ., Stanford, CA.

Ichikura, H., and Ujiie, H., 1976. Lithology and planktonic foraminifera of the Sea of Japan. Bull. Natl. Sci. Museum (Tokyo), Ser. C (Geology), 2:151-181.

Iijima, A., and Tada, R., 1990. Evolution of Tertiary sedimentary basins of Japan in reference to the opening of the Japan Sea. J. Fac. Sci. Univ. Tokyo, 22:121-171.

Iijima, A., Tada, R., and Watanabe, Y., 1988. Development of Neogene sedimentary basins in the northeastern Honshu arc with emphasis on Miocene siliceous deposits. J. Fac. Sci., Univ. Tokyo, 21:417-466.

Ikebe, Y., and Maiya, S., 1981. Akita and Niigata areas. In Tsuchi, R. (Ed.), Neogene of Japan-its Biostratigraphy and Chronology: Shizuoka (Kurofune Printing Co.), 68-75.

Ikuji, Y., 1986. Benthic foraminiferal assemblage in turbidite deposits of the Shiiya and Nishiyama Stages in the Niigata oil field. In Matoba, Y., and 
Kato, M. (Eds.), Studies on Cenozoic Benthic Foraminifera in Japan: Akita (Mining College, Akita University), 135-150.

Ingle, J. C., Jr., 1975. Summary of late Paleogene-Neogene insular stratigraphy, paleobathymetry, and correlations, Philippine Sea and Sea of Japan region. In Karig, D. E., Ingle, J. C., Jr., et al., Init. Repts. DSDP, 31: Washington (U.S. Govt. Printing Office), 837-855.

1981. Origin of Neogene diatomites around the North Pacific rim. In Garrison, R. E., Douglas, R., Pisciotto, K., Isaacs, C., and Ingle, J. C., Jr. (Eds.), The Monterey Formation and Related Siliceous Deposits of California. Soc. Econ. Paleontol. Mineral., Pacific Sect., 159-179.

Ingle, J. C., Jr., Suyehiro, K., von Breymann, M. T., et al., 1990. Proc. ODP, Init. Repts., 128: College Station, TX (Ocean Drilling Program).

Jolivet, L., and Huchon, P., 1989. Crustal scale strike-slip deformation in northern Japan. J. Struct. Geol., 11:509-522.

Jolivet, L., Huchon, P., Brunn, J. P., Le Pichon, X., Chamot-Rooke, N., and Thomas, J. C., 1991. Arc deformation as marginal basin opening: Japan Sea as a case study. J. Geophys. Res., 96:4367-4384.

Jolivet, L., Huchon, P., and Rangin, C., 1989. Tectonic setting of Western Pacific marginal basins. Tectonophysics, 160:23-47.

Kaiho, K., and Hasegawa, S., 1986. Bathymetric distribution of benthic foraminifera in the bottom sediments off Onohama, Fukushima Prefecture, northeast Japan. In Matoba, Y., and Kato, M. (Eds.), Studies on Cenozoic Benthic Foraminifera in Japan: Akita (Akita University), 43-52.

Kanaori, Y., 1990. Late Mesozoic-Cenozoic strike-slip and block-rotation in the inner belt of southwest Japan. Tectonophysics, 177:381-399.

Kaneoka, I., 1986. Constraints on the time of formation of the Japan Sea based on radiometric dates. J. Geomagn. Geoelectr., 38:475-485.

, 1990. Radiometric ages and $\mathrm{Sr}$ isotopic characteristics of the volcanic rocks from the Japan Sea floor. Geochem. J., 24:7-19.

Karig, D. E., Ingle, J. C., Jr., et al., 1975. Init. Repts. DSDP, 31: Washington (U.S. Govt. Printing Office).

Keller, G., 1980. Benthic foraminifers and paleobathymetry of the Japan Trench area, Leg 57, Deep Sea Drilling Project. In von Huene, R., Nasu, N., et al., Init. Repts. DSDP, 56, 57 (Pt. 2): Washington (U.S. Govt. Printing Office), 835-866.

Kent, D. V., 1973. Paleomagnetism of some Neogene sedimentary rocks on Oga Peninsula, Japan. J. Geomagn. Geoelectr., 25:87-103.

Kim, B. K., 1965. The stratigraphic and paleontologic studies of the Tertiary (Miocene) of the Pohang area, Korea. J. Sci. Tech. Seoul Natl. Univ., $15: 32-121$.

, 1970. A study on Neogene Tertiary deposits of Korea. J. Geol. Soc. Korea, 6:77-96.

, 1977. On the Neogene Tertiary deposits in southern Korea. In Saito, T., and Ujiie, H. (Eds.), Proc. First Int. Congr. Pacific Neogene Stratigraphy, 115-118.

1988. Cenozoic biostratigraphy of South Korea. Palaeogeogr. Palaeoclimatol., Palaeoecol., 46:85-96.

Kim, B. K., and Choi, D. K., 1977. Preliminary biostratigraphic zonation by benthonic foraminifers in the Tertiary Pohang Basin, Korea. Proc. College Nat. Sci., Seoul Natl. Univ., 2:155-168.

Kim, W. H., 1990. Significance of early to middle Miocene planktonic foraminiferal biostratigraphy of the E-core in the Pohang basin, Korea. J. Paleontol, Soc. Korea, 6:144-164.

Kimura, G., and Tamaki, K., 1986. Collision, rotation, and back-arc spreading in the region of the Okhostsk and Japan Sea. Tectonics, 5:389-401.

Kitamura, N., Otsuki, K., and Ohguchi, T. (Eds.), 1989. Cenozoic Geotectonics of Northeast Honshu Arc. Chishitsugaku Ronshu, 32.

Kitazato, H., 1975. Geology and geochronology of the younger Cenozoic of the Oga Peninsula. Tohoku Univ., Inst. Geol. Paleontol. Contrib., 75:17-49.

- 1979. Marine paleobathymetry and paleotopography of the Hokuroku district during the time of Kuroko deposition, based on foraminiferal assemblages. Mining Geol., 29:207-216.

Koh, Y. K., 1986. A micropaleontological study on silicoflagellates, ebridians, and nannofossils for the Pohang area, Pohang and Ulleung Basin [Ph.D. dissert.]. Seoul Natl. Univ., Korea.

Koizumi, I., 1988. Early Miocene Proto-Japan Sea. J. Paleontol. Soc. Korea, $4: 6-20$.

Lallemand, S., and Jolivet, L., 1985. Japan Sea: a pull-apart basin. Earth Planet. Sci. Lett., 76:375-389.

Lee, J. S., and Pouclet, A., 1988. Le volcanisme neogene de Pohang (SE Coree), norvelles constraintes geochronologiques pour l'ouverture de la Mer du Japan. C. R. Acad. Sci. Paris Ser. 2, 307:1405-1411.
Lee, Y. G., 1975. Neogene diatoms of Pohang and Ganpo areas, Gyeonsangbug-do, Korea. J. Geol. Soc. Korea, 6:99-114.

, 1984. Micropaleontological (diatoms) study of the Neogene deposits of Korea [Ph.D. dissert.]. Seoul Natl. Univ., Korea.

Ling, H. Y., Ingle, J. C., Jr., and Kim, B. K., 1988. Miocene siliceous biostratigraphy and magnetostratigraphy from the Pohang area, Korea. Paleontol. Soc. Korea, Spec. Vol. IGCP Project 246, 1-5.

Maiya, S., 1978. Late Cenozoic planktonic foraminiferal biostratigraphy of the oil-field region of Northeast Japan. In Huzita, K. (Ed.), Cenozoic Geology of Japan: Osaka (Osaka City Univ.), 35-60.

Maiya, S., Ichinoseki, T., and Akiba, F., 1981. Oshima Peninsula. In Tsuchi, R. (Ed.), Neogene of Japan-its Biostratigraphy and Chronostratigraphy: Shizuoka (Kurofune Printing Co.), 76-80.

Matoba, Y., 1983. A discussion on the estimates of sea depth in the Hokuroko district during the time of Kuroko deposition. In Horikoshi, E. (Ed.), Island Arcs, Marginal Seas, and Kuroko Deposits. Soc. Mining Geol. Jpn., 11:251-261.

Matoba, Y., and Honma, N., 1986. Depth distribution of Recent benthic foraminifera off Nishitsugaru, eastern Sea of Japan. In Matoba, Y., and Kato, M. (Eds.), Studies on Cenozoic Benthic Foraminifera in Japan: Akita (Akita Univ.), 53-78.

Matoba, Y., Tomizawa, A., and Fukasawa, K., 1990. Neogene and Quaternary Sedimentary Sequences in the Oga Peninsula. Guidebook for Field Trip No. 2. Fourth Int. Symp. Benthic Foraminifera, B1-B62.

Matsunaga, T., 1963. Benthonic smaller foraminifera from the oil fields of northern Japan. Sci. Repts. Tohoku Univ., Ser. 2, 35:67-122.

Mayer, L., 1987. Subsidence analysis of the Los Angeles basin. In Ingersoll, R. V., and Ernst, W. G. (Eds.), Cenozoic Basin Development of Coastal California: Englewood Cliffs (Prentice-Hall), 299-326.

, 1991. Central Los Angeles Basin-subsidence and thermal implications for tectonic evolution. In Biddle, K. (Ed.), Active Margin Basins. AAPG Mem., 52:185-1XX

McCrory, P. A., 1989. Late Neogene geohistory of the Humboldt basin and its relationship to convergence of the Juan de Fuca plate. J. Geophys. Res., 94:3126-3138.

Miall, A. D., 1984. Principles of Sedimentary Basin Analysis: New York (Springer-Verlag).

Niitsuma, N., 1978. Magnetic stratigraphy of the Japanese Neogene and the development of island arcs of Japan. J. Phys. Earth, 23:S367-S378.

Nomura, R., 1986. Benthic foraminifera from the strato-type section of the Kuri Formation distributed in Oda City, Shimane Prefecture. In Matoba, Y., and Kato, M. (Eds.), Studies on Cenozoic Benthic Foraminifera in Japan: Akita (Mining College, Akita Univ.), 135-150.

Oba, T., Kato, M., Kitazato, H., Koizumi, I., Omura, A., Sakai, T., and Takayama, T., 1991. Paleoenvironmental changes in the Japan Sea during the last 85,000 years. Paleoceanography, 6:499-518.

Oda, M., 1986. Some aspects and problems concerned with microfossil biochronology for the Neogene in Central and Northern Japan. In Nakagawa, H., Kotaka, T., and Takayanagi, Y.(Eds.), Essays in Geology: Sendai (Tohoku Univ.), 297-312.

Ogasawara, K., Hirooka, K., Koizumi, I., Fukusawa, T., and Takayama, T., 1991. Neogene Evolution of the Japan Sea Side. Guidebook for Field Trip No. 1, Fifth Int. Congr. Pacific Neogene Stratigraphy: Shizuoka (Kurofune Printing Co.).

Ohmoto, H., 1983. Geologic history of the Green Tuff region. In Ohmoto, H., and Skinner, B. J. (Eds.), The Kuroko and Related Volcanogenic Massive Sulfide Deposits. Econ. Geol. Monogr., 5:9-23.

Ohmoto, H., and Skinner, B. J. (Eds.), 1983. The Kuroko and Related Volcanogenic Massive Sulfide Deposits. Econ. Geol. Monogr., 5.

Ota, Y. T., 1973. Late Quaternary vertical movement in Japan estimated from deformed shorelines. In Suggate, R. P., and Cresswell, M. M. (Eds.), Quaternary Studies. R. Soc. N.Z. Bull., 13:231-239.

Ota, Y. T., Matsuda, T., and Naganuma, K., 1976. Tilted marine terraces of the Oga Peninsula, Sado Island, central Japan, related to the Ogi earthquake of 1802. J. Seismol. Soc. Jpn., 29:55-70.

Otofuji, Y., Itaya, T., and Matsuda, T., 1991. Rapid rotation of southwest Japan-palaeomagnetism and $\mathrm{K}-\mathrm{Ar}$ ages of Miocene volcanic rocks of southwest Japan. Geophys. J. Int., 105:397-405.

Otofuji, Y., and Matsuda, T., 1983. Paleomagnetic evidence for clockwise rotation of southwest Japan. Earth Planet. Sci. Lett., 62:349-359.

1987. Amount of clockwise rotation of southwest Japan-fan shaped opening of the southwestern part of the Japan Sea. Earth Planet. Sci. Lett., 85:289-301. 
Otofuji, Y., Matsuda, T., and Nohda, S., 1985. Paleomagnetic evidence for counter-clockwise rotation of Northeast Japan-rifting process of the Japan Arc. Earth Planet. Sci. Lett., 75:265-277.

Parsons, B., and Sclater, J. G., 1977. An analysis of variation of sea floor bathymetry with heat flow and age. J. Geophys. Res., 82:803-827.

Pitman, W. C., and Andrews, J. A., 1985. Subsidence and thermal history of small pull-apart basins. In Biddle, K. T., and Christie-Blick, N. (Eds.), Strike-slip Deformation, Basin Formation, and Sedimentation. Spec. Publ.-Soc. Econ. Paleontol. Mineral., 37:45-49.

Reedman, A. J., and Um, S. H., 1975. The Geology of Korea: Seoul (Geol. and Mineral Inst. of Korea).

Saito, T., 1981. Haboro-Embetsu area. In Tsuchi, R. (Ed.), Neogene of Japanits Biostratigraphy and Chronostratigraphy: Shizuoka (Kurofune Printing Co.), 81-84.

Salnikov, B. A., Arkhipova, A. D., Brutman, N. Y., Zhidkova, L. S., Kuznetsova, V. N., Melnikov, O. A., Moiseyeva, A. I., Popova, L. A., Sergeyeva, V. B., Fotianova, L. I., Shainyan, S. K., and Sheremetieva, G. N., 1979. The Makarovsky Key Section of Paleogene and Neogene Deposits in Sakhalin-Guidebook. XIV Pacific Sci. Congr., 1-19.

Sato, T., Baba, K., Ohguchi, T., and Takayama, T., 1991. Discovery of early Miocene calcareous nannofossils from Japan Sea side, northern Honshu, Japan, with reference to paleoenvironment in the Daijima and Nishikurosawa ages. Jpn. Assoc. Pet. Tech., 56:263-279.

Sato, T., and Kudo, T., 1986. Paleoenvironmental change of early Pleistocene in the Niigata oil field area as indicated by the foraminiferal fauna. In Matoba, Y., and Kato, M. (Eds.), Studies on Cenozoic Benthic Foraminifera in Japan: Akita (Mining College, Akita Univ.), 105-114.

Serova, M. Y., 1978. Stratigraphy and foraminifers of the Neogene of Kamchatka. Trans. Acad. Sci. U.S.S.R., 323:1-174.

Serova, M. Y., Fotyanova, L. I., Linkova, T. I., and Remzovsky, V. I., 1981. Relationship between biostratigraphic and magnetostratigraphic levels of the Neogene in the north-west Pacific. In Ikebe, N., Chiji, M., Tsuchi, R. Morozumi, Y., and Kawata, T. (Eds.), Proc. IGCP-I14 Intern. Workshop Pacific Neogene Biostratigraphy: Osaka (Osaka Mus. Nat. History), 137-138.

Steckler, M. S., and Watts, A. B., 1978. Subsidence of Atlantic-type continental margin off New York. Earth Planet. Sci. Lett., 41:1-13.

Sugi, N., Chinzei, K., and Uyeda, S., 1983. Vertical crustal movements of north-east Japan since middle Miocene. In Hilde, T. W., and Uyeda, S. (Eds.), Geodynamics of the Western Pacific-Indonesian Region. Am. Geophys. Union, Geodyn. Ser., 1:317-330.

Suzuki, T., 1980. Fission track ages of the Tertiary volcanic rocks in the Oga Peninsula, northern Japan. Chishitsugaku Zasshi, 86:441-453.

Takayama, T., 1977. On the geologic age of the "Hojuji diatomaceous mudstone" Noto Peninsula, based on calcareous nannofossils. Ann. Sci. Kanazawa Univ., 14:71-79.

Takayasu, T., and Matoba, Y. (Eds.), 1976. Oga Peninsula. Guidebook for Excursion I. First Int. Congr. Pacific Neogene Stratigraphy: Shizuoka (Kurofune Printing Co.), 1-78.

Tamaki, K., 1986. Age estimation of the Japan Sea on the basis of stratigraphy, basement depth, and heat flow data. J. Geomagn. Geoelectr., 38:427-446.

1988. Geological structure of the Sea of Japan and its tectonic implications. Chishitsu Chosasho Geppo, 39:269-365.

Tamaki, K., and Honza, E., 1985. Incipient subduction and obduction along the eastern margin of the Japan Sea. Tectonophysics, 119:381-406.

Tamaki, K., and Kobayashi, K., 1988. Geomagnetic anomaly lineation in the Japan Sea. Mar. Sci. Monthly, 20:705-710.
Tamaki, K., Pisciotto, K., Allan, J., et al., 1990. Proc. ODP, Init. Results, 127: College Station, TX (Ocean Drilling Program).

Tanimura, S., Date, J., Takahashi, T., and Ohomoto, H., 1983. Stratigraphy and structure of the Hokuroku District. In Ohmoto, H., and Skinner, B. J. (Eds.), The Kuoroko and Related Volcanogenic Massive Sulfide Deposits. Econ. Geol. Monogr., 5:24-38.

Tochilina, S. V., 1986. Biostratigraphy of the Cenozoic North-western Pacific Ocean: Moscow (Nauka).

Tochilina, S. V., Vagina, N. K., Popova, I. M., and Remizovsky, V. I., 1988. Late Cenozoic of the Southern Sakhalin (reference sections rivers Maly, Takov, Bachinskaya). U.S.S.R. Acad. Sci., Far Eastern Branch.

Tsoy, I. B., 1988. Neogene diatom assemblages of the Japan Sea. In Simola, H. (Ed.), Proc. 10th Int. Diatom Symp., Koenigstein (Koeltz Sci. Books), 223-231.

Tsuchi, R. (Ed.), 1981a. Neogene of Japan-its Biostratigraphy and Chronology: Shizuoka (Kurofune Printing Co.).

1981b. Fundamental Data on Japanese Neogene Bio- and Chronostratigraphy-Supplement: Shizuoka (Kurofune Print. Co., Ltd.).

Tsuchi, R., and IGCP-114 Working Group of Japan, 1981. Bio- and chronostratigraphic correlation of Neogene sequences in the Japanese Islands. In Tsuchi, R. (Ed.), Neogene of Japan-its Biostratigraphy and Chronology: Shizuoka (Kurofune Printing Co.), 91-104.

Tsuchi, R., Takayanagi, Y., and Shibata, K., 1981. Neogene bioevents in the Japanese Islands. In Tsuchi, R. (Ed.), Neogene of Japan-its Biostratigraphy and Chronology: Shizuoka (Kurofune Printing Co.), 15-32.

Tsuchiya, N., 1990. Middle Miocene back-arc rift magmatism of basalt in the NE Japan arc. Bull. Geol. Soc, Japan, 41:473-504.

Ujiie, H., and Ichikura, M., 1973. Holocene to uppermost Pleistocene planktonic foraminifera in a piston core from off the Sanin District, Sea of Japan. Trans. Palaeontol. Soc. Jpn., 9:137-150.

Um, S. H., Lee, D. W., and Park, B. S., 1964. Geological Map of Korea, Pohang Sheet. Geol. Surv. Korea. (scale 1:50,000).

Van Hinte, J. E., 1978. Geohistory analysis - an application of micropaleontology in exploration geology. AAPG Bull., 62:201-222.

von Huene, R., and Arthur, M., 1982. Sedimentation across the Japan Trench off northern Honshu Island. In Leggett, J. K. (Ed.), Trench-forearc Geology: Sedimentation and Tectonics on Modern and Ancient Active Plate Margins: Oxford (Blackwell Sci. Publ.), 27-48.

von Huene, R., Langseth, M., Nasu, N., and Okada, H., 1982. A summary of Cenozoic tectonic history along IPOD Japan Trench transect. Geol. Soc. Am. Bull., 93:829-846.

Yamaji, A., and Sato, H., 1989. Miocene subsidence of the Northeast Honshu Arc and its mechanism. In Kitamua, N., Otsuki, K., and Ohguchi, T. (Eds.), Cenozoic Geotectonics of Northeast Honshu Arc. Chishitsugaku Ronshu, 32:339-349.

Yoo, E. K., 1969. Tertiary foraminifera from the PY-1 well, Pohang Basin, Korea. J. Geol. Soc. Korea, 5:77-96.

Yoon, S., 1975. Geology and paleontology of the Tertiary Pohang district, Korea. J. Geol. Soc. Korea, 11:187-214.

Yoshii, T., and Asano, S., 1972. Time-term analysis of explosion seismic data. J. Phys. Earth, 20:47-57.

Date of initial receipt: 13 March 1992

Date of acceptance: 16 April 1992

Ms 127/128B-132 